\title{
Ketone-Imide versus Ketone-Oxime Reductive Cross-Coupling Promoted by Samarium Diiodide: New Mechanistic Insight Gained from a Failed Aminocyclopentitol Synthesis
}

\author{
Jose Luis Chiara,* Ángela García, and Gabriella Cristóbal-Lumbroso \\ Instituto de Química Orgánica General, CSIC, Juan de la Cierva 3, E-28006 Madrid, Spain \\ jl.chiara@iqog.csic.es
}

Received January 28, 2005

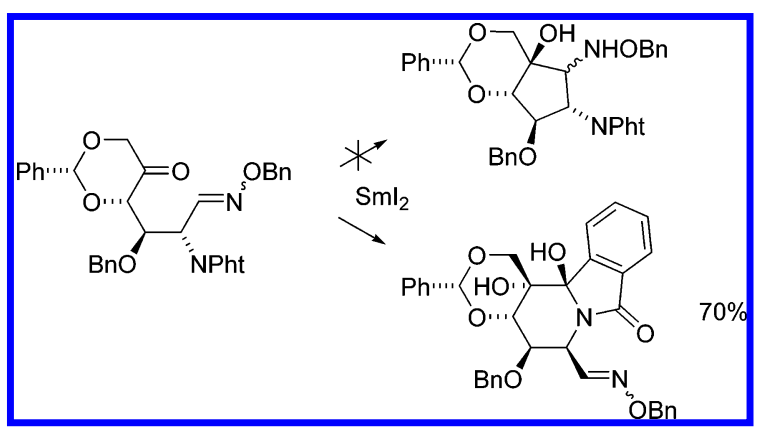

The intramolecular 1,6-ketone/imide reductive coupling promoted by samarium diiodide competes favorably with an alternative 1,5-ketone/oxime ether coupling in a keto-oxime substrate derived from D-glucosamine $\mathrm{N}$-protected with a phthalimido group. This pinacol coupling reaction affords new homochiral $\alpha$-hydroxylactam scaffolds that could be useful in diversity-oriented synthesis. A mechanistic proposal for this reaction that explains the experimental results is supported by DFT quantum-mechanical calculations on model compounds.

\section{Introduction}

The stereochemical diversity and high degree of functionalization of carbohydrates render them particularly attractive as scaffolds for the synthesis of libraries of polyfunctional, rigid, and geometrically diverse compounds suitable for broad screeening. ${ }^{1}$ Pyranose $^{2}$ and, less frequently, their furanose ${ }^{3}$ counterparts have been mostly used in this endeavor. Carbocycles derived from carbohydrates represent an interesting alternative that remains little explored. ${ }^{4}$ In the context of our work ${ }^{5}$ on the synthesis of natural products with an aminocyclopentitol moiety using carbohydrates as starting materials, we became interested in the preparation of libraries of compounds based on polyhydroxylated diaminocyclopentane scaffolds (I) for the discovery of new and specific glycosidase inhibitors inspired in the structure of natural carbocyclic inhibitors ${ }^{6}$ (Chart 1 ).

(1) For recent reviews, see: (a) Le Giang, T.; Abbenante, G.; Becker, B.; Grathwohl, M.; Halliday, J.; Tometzki, G.; Zuegg, J.; Meutermans, W. Drug Discovery Todav 2003, 8, 701-709. (b) Marcaurelle, L. A.; Seeberger, P. H. Curr. Opin. Chem. Biol. 2002, 6, 289-296. (c) Gruner, S. A. W.; Locardi, E.; Lohof, E.; Kessler, H. Chem. Rev. 2002, 102, 491514.
In formulating the synthetic plan for the 1,2-diaminocyclopentane skeleton I, we envisioned the use of D-glucosamine IV as a readily available homochiral

(2) (a) Hirschmann, R.; Nicolaou, K. C.; Pietranico, S.; Salvino, J.; Leahy, E. M.; Sprengeler, P. A.; Furst, G.; Strader, C. D.; Smith, A B., III; Cascieri, M. A.; Candelore, M. R.; Donaldson, C.; Vale, W. Maechler, L. J. Am. Chem. Soc. 1992, 114, 9217-9218. (b) Hirschmann, R.; Nicolaou, K. C.; Pietranico, S.; Leahy, E. M.; Salvino, J.; Arison, B.; Cichy, M. A.; Spoors, P. G.; Shakespeare, W. C.; Sprengeler, P. A.; Hamley, P.; Smith, A. B., III; Reisine, T.; Raynor, K.; Maechler, L.; Donaldson, C.; Vale, W.; Freidinger, R. M.; Cascieri, M. R.; Strader, C. D. J. Am. Chem. Soc. 1993, 115, 12550-12568. (c) Nicolaou, K. C.; Trujillo, J. I.; Chibale, K. Tetrahedron 1997, 53, 8751-8778. (d) Sofia, M. J.; Hunter, R.; Chan, T. Y.; Vaughan, A.; Dulina, R.; Wang, H.; Gange, D. J. Org. Chem. 1998, 63, 2802-2803. (e) Wong, C.-H.; Hendrix, M.; Manning, D. D.; Rosenbohm, C.; Greenberg, W. A. J. Am. Chem. Soc. 1998, 120, 8319-8327. (f) Wunberg, T.; Kallus, C.; Opatz, T.; Henke, S.; Schmidt, W.; Kunz, H. Angew. Chem., Int. Ed. 1998, 37, 2503-2505. (g) Kallus, C.; Opatz, T.; Wunberg, T.; Schmidt, W.; Henke, S.; Kunz, H. Tetrahedron Lett. 1999, 40, 7783-7786. (h) Hirschmann, R.; Ducry, L.; Smith, A. B., III. J. Org. Chem. 2000, 65, 8307-8316. (i) Hanessian, S.; Saavedra, O. M.; Xie, F.; Amboldi, N.; Battistini, C. Bioorg. Med. Chem. Lett. 2000, 10, 439-442. (j) Opatz, T.; Kallus, C.; Wunberg, T.; Schmidt, W.; Henke, S.; Kunz, H. Carbohydr. Res. 2002, 337, 2089-2110. (k) Opatz, T.; Kallus, C.; Wunberg, T.; Schmidt, W.; Henke, S.; Kunz, H. Eur. J. Org. Chem. 2003, 1527-1536. (l) Murphy, P. V.; O’Brien, J. L.; Gorey-Feret, L. J.; Smith, A. B., III. Tetrahedron 2003, 59, 2259-2271. (m) Abrous, L.; Jokiel, P. A.; Friedrich, S. R.; Hynes, J.; Smith, A. B., III; Hirschmann, R. J. Org. Chem. 2004, 69, 280-302. (n) Huenger, U.; Ohnsmann, J.; Kunz, H. Angew. Chem. Int. Ed. 2004, 43, 1104-1107. 
CHART 1. Natural Aminocyclopentitol Glycosidase Inhibitors and Structurally Related Compounds

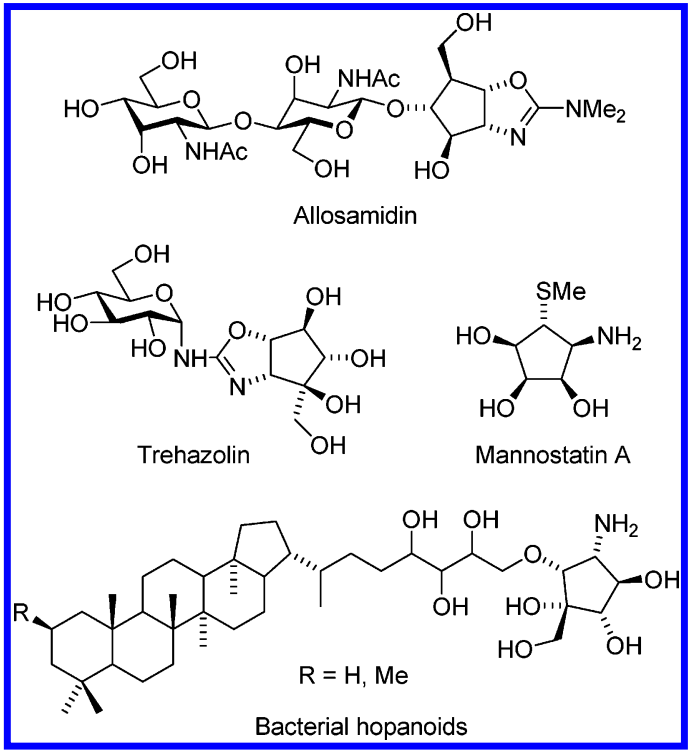

SCHEME 1

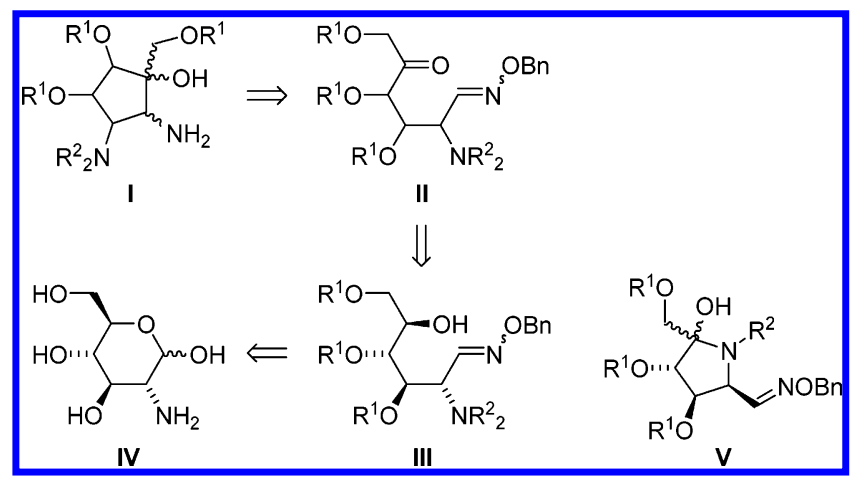

starting material and a ketone-oxime ether reductive carbocyclization and hydroxylamine reduction cascade ${ }^{5}$ promoted by $\mathrm{SmI}_{2}$ as an effective tool to prepare the key carbocycle I (Scheme 1).

\section{Results and Discussion}

Initial attempts at preparing target cyclopentitol I by reductive cyclization of keto-oximes II met with failure. Thus, oxidation of oxime III $\left(\mathrm{R}^{1}=\mathrm{Bn}\right)$ under Swern

(3) (a) Papageorgiou, C.; Haltiner, R.; Bruns, C.; Petcher, T. J. Bioorg. Med. Chem. Lett. 1992, 2, 135. (b) Krueger, E. B.; Hopkins, T. P.; Keaney, M. T.; Walters, M. A.; Boldi, A. M. J. Comb. Chem. 2002, 4, 229-238. (c) Timmer, M. S. M.; Verdoes, M.; Sliedregt, L.; van der Marel, G. A.; van Boom, J. H.; Overkleeft, H. S. J. Org. Chem. 2003, $68,9406-9411$.

(4) Phon, C. W.; Abell, C. J. Comb. Chem. 1999, 1, 485-492.

(5) (a) Chiara, J. L.; Marco-Contelles, J.; Khiar, N.; Gallego, P.; Destabel, C.; Bernabe, M. J. Org. Chem. 1995, 60, 6010-11. (b) MarcoContelles, J.; Gallego, P.; Rodriguez-Fernandez, M.; Khiar, N.; Destabel, C.; Bernabe, M.; Martinez-Grau, A.; Chiara, J. L. J. Org. Chem. 1997, 62, 7397-7412. (c) Storch de Gracia, I.; Dietrich, H.; Bobo, S.; Chiara, J. L. J. Org. Chem. 1998, 63, 5883-5889. (d) Storch de Gracia, I.; Bobo, S.; Martin-Ortega, M. D.; Chiara, J. L. Org. Lett. 1999, 1, 1705-1708. (e) Bobo, S.; Storch de Gracia, I.; Chiara, J. L. Synlett 1999, 1551-1554. (f) Chiara, J. L.; Storch de Gracia, I.; Bastida, A. Chem. Commun. 2003, 1874-1875. (g) Chiara, J. L.; Storch de Gracia, I.; García, A.; Bastida, Á.; Bobo, S.; Martín-Ortega, M. ChemBioChem 2005, 6, 186-191.

(6) Berecibar, A.; Grandjean, C.; Siriwardena, A. Chem. Rev. 1999, $99,779-844$.

\section{SCHEME $2^{a}$}

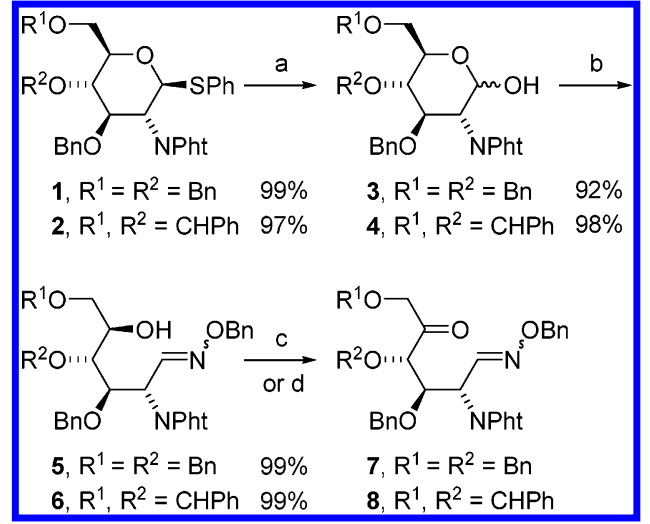

${ }^{a}$ Reagents and conditions: (a) NBS, acetone/ $\mathrm{H}_{2} \mathrm{O}$ (10:1), -15 ${ }^{\circ} \mathrm{C}$ to rt; (b) $\mathrm{BnONH}_{2} \cdot \mathrm{HCl}$, pyridine, $\mathrm{MeOH}, 50{ }^{\circ} \mathrm{C}$; (c) Dess-Martin periodinane, $\mathrm{CH}_{2} \mathrm{Cl}_{2}$, rt (7); (d) (i) $(\mathrm{COCl})_{2}, \mathrm{DMSO}, \mathrm{CH}_{2} \mathrm{Cl}_{2},-70$ ${ }^{\circ} \mathrm{C}$, (ii) $\mathrm{Et}_{3} \mathrm{~N},-70{ }^{\circ} \mathrm{C}$ to $\mathrm{rt}(8)$.

conditions or using the Dess-Martin reagent followed by column chromatography purification provided exclusively the cyclic hemiaminal $\mathbf{V}$ when the amino group was monoprotected as an acetamide or as a $t$-BOC carbamate. Surprisingly, ${ }^{7}$ when a Swern oxidation/reductive coupling protocol $^{5 f}$ was employed to avoid the isolation of the intermediate ketone, a complex mixture of products was obtained from which the expected diaminocyclopentitol I could not be isolated. In an attempt to overcome these unanticipated difficulties, we selected the $N$-phthalimido group as a more suitable protecting group for the amino function of our substrate. In doing this selection, we were confronted with a different potential problem, as it has been recently shown that imides are able to cross-couple inter- ${ }^{8}$ and intramolecularly ${ }^{9}$ with carbonyl compounds in the presence of $\mathrm{SmI}_{2}$. However, we expected that the ketone-oxime ether cross-coupling could successfully compete because oxime ethers are highly efficient Cradical acceptors. ${ }^{5,10}$ In addition, the ketone/oxime ether cross-coupling reaction, being a 5-exo-trig cyclization in this case, would have an entropic advantage over the alternative 6-exo-trig ketone/imide reaction.

Two differently $O$-protected keto-oximes, $\mathbf{7}$ and $\mathbf{8}$, were selected as substrates for the pinacol coupling reaction (Scheme 2). These compounds were readily obtained from the known protected D-glucosamine derivatives $\mathbf{1}^{11}$ and $\mathbf{2 , 1 2}$ respectively, following a three-step sequence ${ }^{5 \mathrm{~d}}$ that consists of: (i) mild hydrolysis of the thiophenyl glycoside

(7) We had successfully used previously our one-pot oxidationreductive coupling protocol for the carbocyclization of a closely related keto-aldehyde derived from D-glucosamine protected as $N$-acetamide or as $N$-t-Boc carbamate. ${ }^{5 f}$

(8) (a) Farcas, S.; Namy, J.-L. Tetrahedron Lett. 2000, 41, 72997302. (b) Yoda, H.; Matsuda, K.; Nomura, H.; Takabe, K. Tetrahedron Lett. 2000, 41, 1775-1780.

(9) Yoda, H.; Nakahama, A.; Koketsu, T.; Takabe, K. Tetrahedron Lett. 2002, 43, 4667-4670.

(10) (a) Bartlett, P. A.; McLaren, K. L.; Ting, P. C. J. Am. Chem. Soc. 1988, 110, 1633-1634. (b) Grissom, J. W.; Klingberg, D. J. Org. Chem. 1993, 58, 6559-64. (c) Kim, S.; Kim, Y.; Yoon, K. S. Tetrahedron Lett. 1997, 38, 2487-2490. (d) Miyabe, H.; Shibata, R.; Sangawa, M.; Ushiro, C.; Naito, T. Tetrahedron 1998, 54, 11431-11444. For recent reviews, see: (e) Fallis, A. G.; Brinza, I. M. Tetrahedron 1997, 53, 17543-17594. (f) Friestad, G. K. Tetrahedron 2001, 57, 5461-5496.

(11) Sofia, M.; Allanson, N.; Chen, A.; Liu, D.; Chan, T. Y. PCT Int. Appl., WO 9734623, 1997.

(12) Ogawa, T.; Nakabayashi, S.; Sasajima, K. Carbohydr. Res. 1981, $95,308-312$ 


\section{SCHEME 3}

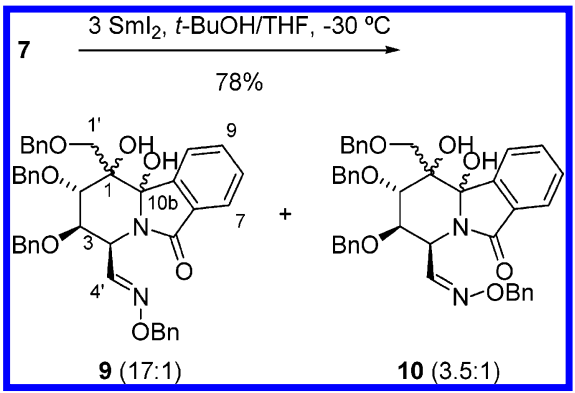

SCHEME $4^{a}$

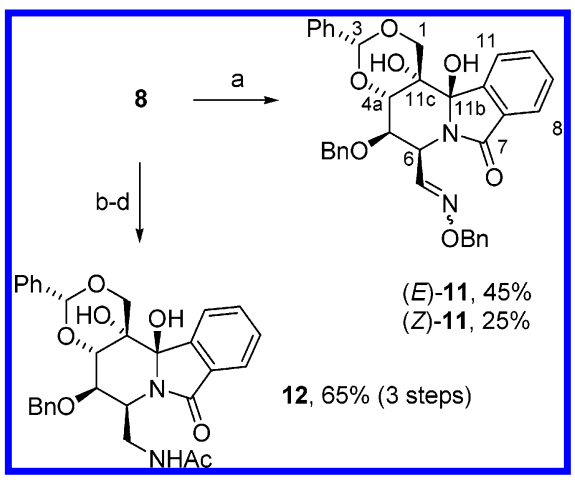

${ }^{a}$ Reagents and conditions: (a) $\mathrm{SmI}_{2}$ (3 equiv), $t$ - $\mathrm{BuOH} / \mathrm{THF},-30$ ${ }^{\circ} \mathrm{C}$; (b) $\mathrm{SmI}_{2}$ (6.7 equiv), $t$-BuOH/THF, $-30{ }^{\circ} \mathrm{C}$ to $\mathrm{rt}$; (c) $\mathrm{H}_{2} \mathrm{O}(30$ equiv); (d) $\mathrm{Ac}_{2} \mathrm{O}$, pyridine.

under oxidative conditions, ${ }^{13}$ (ii) condensation with $O$ benzylhydroxylamine, and (iii) oxidation under Swern conditions or using the Dess-Martin periodinane. Ketooximes $\mathbf{7}$ and $\mathbf{8}$ were obtained as a mixture of isomeric oxime ethers $[E / Z$ ratio $=4.7: 1(\mathbf{7}), 2.5: 1(8)]$.

When the mixture of keto-oximes $\mathbf{7}$ was treated with a solution of $\mathrm{SmI}_{2}$ (3 equiv) in THF containing $t$-BuOH at $-30{ }^{\circ} \mathrm{C}$, a fast intramolecular pinacol coupling reaction took place, but instead of the expected cyclopentitol I, a mixture of four diastereoisomeric tricyclic $\alpha$-hydroxylactams was formed in good yield (Scheme 3). This mixture could be separated by column chromatography into $(E)$ oxime $\mathbf{9}(17: 1)$ and $(Z)$-oxime $\mathbf{1 0}(3.5: 1)$, each as a mixture of diastereoisomers at the new stereocenters. The $\mathbf{9} / \mathbf{1 0}$ ratio was $1.3: 1$, as determined by ${ }^{1} \mathrm{H}$ NMR analysis of the crude reaction mixture. The stereochemistry at the two new stereocenters in these mixtures could not be determined due to strong spectral overlap. On the other hand, cyclization of keto-oximes $\mathbf{8}$ under the same conditions yielded a separable mixture of two diastereoisomeric $\alpha$-hydroxylactams, $(E)-\mathbf{1 1}{ }^{14}$ and $(Z)-\mathbf{1 1},{ }^{14}$ which differed only in the configuration of the oxime group (Scheme 4). As was previously observed for related reductive cyclizations involving a cyclic ketone, ${ }^{5 \mathrm{~d}, \mathrm{e}, 15}$ a single stereoisomer is obtained at the quaternary carbinol center arising from the ketone carbonyl. When a large

(13) (a) Groneberg, R. D.; Miyazaki, T.; Stylianides, N. A.; Schulze, T. J.; Stahl, W.; Schreiner, E. P.; Suzuki, T.; Iwabuchi, Y.; Smith, A. L.; Nicolaou, K. C. J. Am. Chem. Soc. 1993, 115, 7593. (b) Motawia, M. S.; Marcussen, J.; Moeller, B. L. J. Carbohydr. Chem. 1995, 14, 1279.

(14) The structure of all new compounds was determined by $1 \mathrm{D}$ NMR $\left({ }^{1} \mathrm{H}\right.$ and ${ }^{13} \mathrm{C}$ ) and 2D NMR (DQ-COSY, NOESY, HSQC, and HMBC) experiments (see the Supporting Information).

(15) Boiron, A.; Zilling, P.; Faber, D.; Giese, B. J. Org. Chem. 1998 $63,5877-5882$ excess of $\mathrm{SmI}_{2}$ (6.7 equiv) was used, reduction of the oxime to the amine took place upon addition of $\mathrm{H}_{2} \mathrm{O}^{5 \mathrm{a}-\mathrm{e}}$ to give compound $\mathbf{1 2}^{14}$ after $N$-acetylation, isolated as a single diastereoisomer.

The stereochemistry of the two contiguous quaternary carbons of compounds $\mathbf{1 1}$ and $\mathbf{1 2}$ was determined through a combination of molecular modeling and NMR studies. First, geometry optimization calculations were performed for the four possible diastereoisomers at the two contiguous carbinol centers (two trans and two cis diols) of compound $(E)$-11 using the MM2 force field. To reduce the number of possible conformers, $O$-benzyl ethers were replaced by $O$-methyl ethers in this theoretical study. Figure 1 shows the calculated geometries of the global minimum energy conformer for each diasteroisomer. Due to its rather rigid polycyclic structure, other possible ring conformers lie $>2 \mathrm{kcal} / \mathrm{mol}$ above the global minimum, thus allowing their exclusion. Inspection of all of the minimized structures revealed that the distance between the aromatic proton ortho to the aminal group $(\mathrm{H}-11)$ and the methylenic protons at $\mathrm{C}-1$ ( $\mathrm{H}-1 \mathrm{a}$ and $\mathrm{H}-1 \mathrm{~b})$ could be of diagnostic value for the stereochemical assignment. The pertinent interproton distances are reported in Table 1 together with the total energies calculated for each conformer. Next, a full assignment of the ${ }^{1} \mathrm{H}$ and ${ }^{13} \mathrm{C}$ NMR signals of compounds $\mathbf{1 1}$ and $\mathbf{1 2}$ was performed by a combination of DQ-COSY, HSQC, HMBC, and NOESY spectra (see the Supporting Information). Figure 2 shows selected NOESY correlations observed for these compounds. Protons H-1a $(\delta 4.30,4.17$, and $4.31 \mathrm{ppm}$ in $(E)$ 11, $(Z)-11$, and 12, respectively) and $\mathrm{H}-1 \mathrm{~b}(\delta 4.58,4.50$, and $4.74 \mathrm{ppm}$ in $(E)-\mathbf{1 1},(Z)-\mathbf{1 1}$, and 12, respectively) were readily differentiated in the NOESY spectra, because only $\mathrm{H}-1 \mathrm{~b}$ showed a cross-peak with the acetalic proton H-3 $(\delta 5.68,5.72$, and $5.81 \mathrm{ppm}$ in $(E)-\mathbf{1 1},(Z)-\mathbf{1 1}$, and 12, respectively). The assignment of the $\mathrm{H}-11$ resonance $(\delta 7.45,7.42$, and $7.51 \mathrm{ppm}$ in $(E)-\mathbf{1 1},(Z)-\mathbf{1 1}$, and 12, respectively) was straightforward too because this is the only aromatic proton that gave a cross-peak with the aminal carbon $\mathrm{C}-11 \mathrm{~b}(\delta 88.6,89.3$, and $89.6 \mathrm{ppm}$ in $(E)$ 11, $(Z)-11$, and 12, respectively) in the HMBC spectra (optimized for an average ${ }^{\mathrm{n}} J_{\mathrm{CH}}$ value of $8 \mathrm{~Hz}$ ). The NOESY spectra of compounds $(E)-\mathbf{1 1},(Z)-\mathbf{1 1}$, and $\mathbf{1 2}$ showed a cross-correlation of $\mathrm{H}-11$ with $\mathrm{H}-1$ a but not with $\mathrm{H}-1 \mathrm{~b}$, thus excluding the two isomers with an $(R)$ configuration at $\mathrm{C}-11 \mathrm{c}$, for which the predicted $\mathrm{H}-11 / \mathrm{H}-$ 1a distance is $>3.5 \AA$ (see Table 1). NOESY correlations between the hydroxyl protons and proximal $\mathrm{CH}$ protons of the molecule allowed us to assign the $(R)$-configuration to $\mathrm{C}-11 \mathrm{~b}$ quaternary center and confirmed the previous assignment of the $(S)$-configuration to $\mathrm{C}-11 \mathrm{c}$. Thus, the $\mathrm{OH}$ at $\mathrm{C}-11 \mathrm{c}(\delta 2.83,2.87$, and $2.90 \mathrm{ppm}$ in $(E)-\mathbf{1 1},(Z)-$ 11, and 12, respectively) gives cross-peaks with $\mathrm{H}-1 \mathrm{a}$ and $\mathrm{H}-5$, as expected for a $(11 \mathrm{cS})$-stereochemistry. Conversely, the hemiaminal hydroxyl at C-11b $(\delta 5.41,7.50 \mathrm{ppm}$ in $(E)-\mathbf{1 1}$ and 12, respectively; this signal could not be observed in $(Z)$-11 due to fast exchange catalyzed by acidic impurities) showed cross-correlation with $\mathrm{H}-1 \mathrm{~b}$, as expected for a $(11 \mathrm{~b} R)$-stereochemistry. In the case of the acetamido derivative 12, the displacement to low field $(\Delta \delta=+2.09 \mathrm{ppm}$, with respect to $(E)-\mathbf{1 1})$ of the ${ }^{1} \mathrm{H}$ signal of the hydroxyl at $\mathrm{C}-11 \mathrm{~b}$ reveals the involvement of this proton in a stable intramolecular hydrogen bond. The global energy minimum conformation calculated for the 


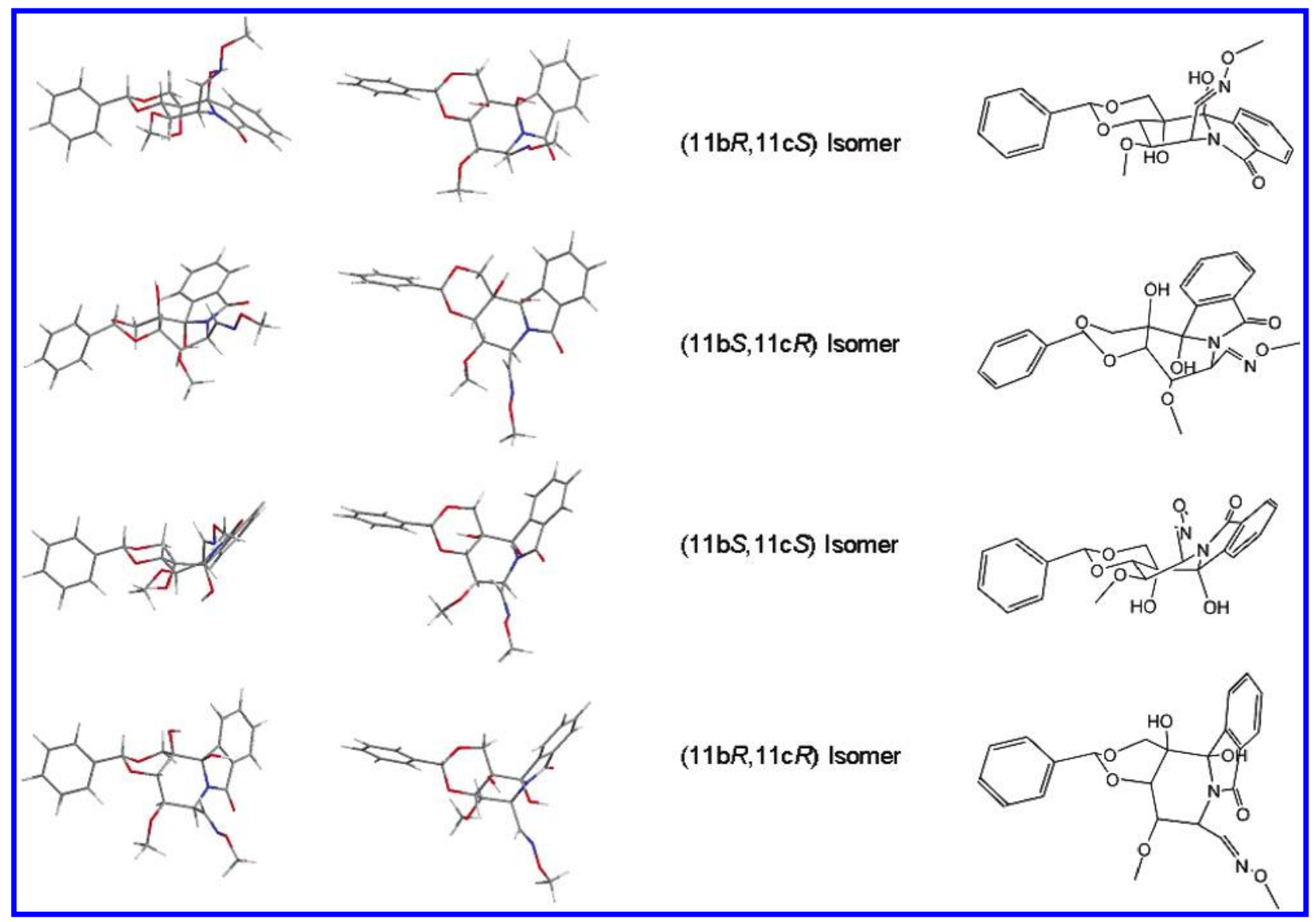

FIGURE 1. Global minimum energy conformers of the four possible diastereoisomers of a methyl ether analogue of compound (E)-11 calculated in the gas phase using the MM2 force field. Two different views, from perpendicular planes, are shown for each isomer together with the corresponding structural formula.

TABLE 1. Calculated MM2 Gas-Phase Total Energies and Selected Through-Space Interproton Distances for the Global Energy Minimum Conformers of the Four Possible Diastereoisomers of a Methyl Ether Analogue of Compound $(E)-11$

\begin{tabular}{cccc} 
& \\
\hline & & \\
\hline
\end{tabular}

$(11 \mathrm{~b} R, 11 \mathrm{cS})$-isomer of this compound using the MM2 force field (Figure 3) correctly predicts this situation, revealing the presence of a nine-membered ring hydrogen bond with the acetamido carbonyl group. The interproton distances calculated for this optimized structure, in particular those involving the methylenic protons of the side chain at C-6 (see Table in Figure 2), completely agree with the NOESY cross-peaks observed for 12 (Figure 2).

The fact that no cyclopentitol arising from the alternative ketone/oxime ether pinacol coupling was detected in

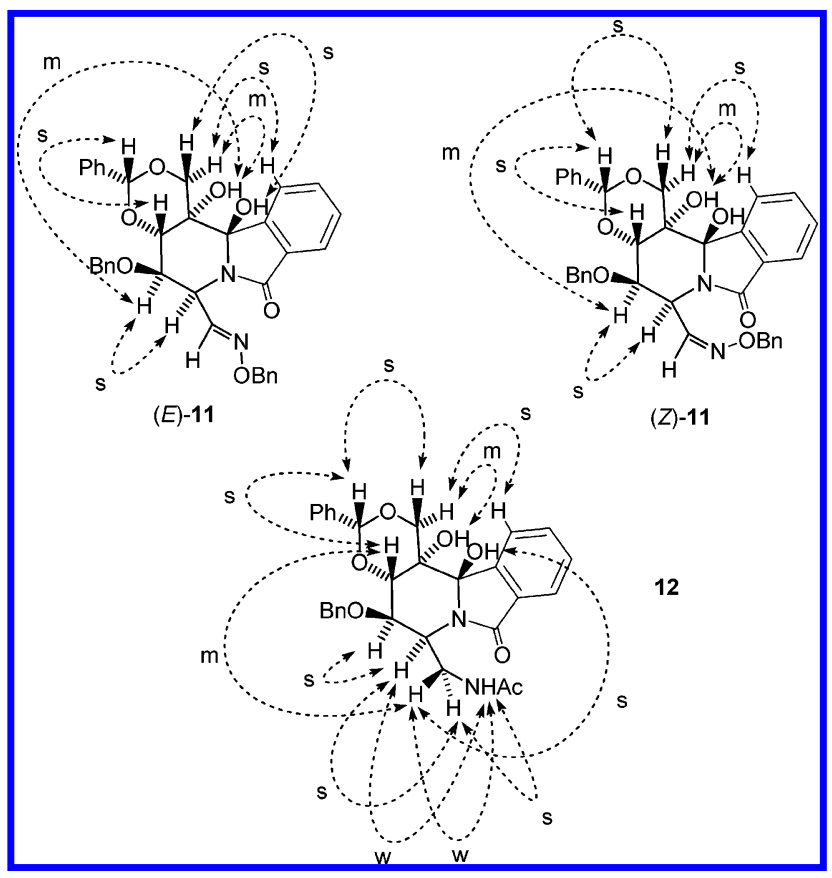

FIGURE 2. Selected NOESY correlations measured for compounds $(E / Z)-11$ and 12 in $\mathrm{CDCl}_{3}$ at $27^{\circ} \mathrm{C}$.

the crude reaction mixtures provides some clues on the possible mechanistic pathway of this reductive process (Scheme 5). Thus, the experimental observations can be 


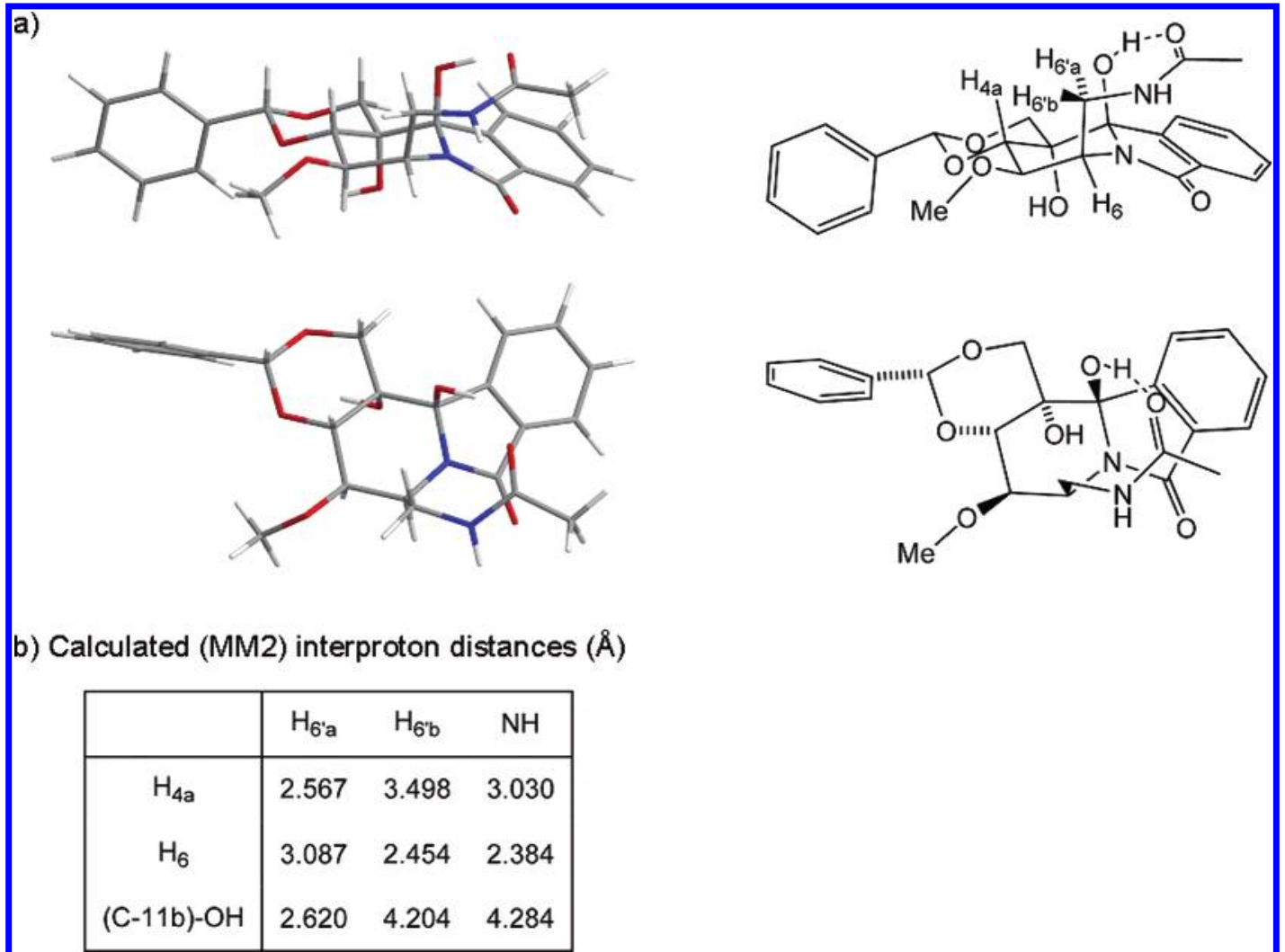

FIGURE 3. Global minimum energy conformer (a) and selected interproton distances (b) of a methyl ether analogue of compound 12 calculated in the gas phase using the MM2 force field. Two different views, from perpendicular planes, are shown together with the corresponding structural formula.

SCHEME 5. Mechanistic Proposal for the Intramolecular Ketone/Imide Reductive Coupling

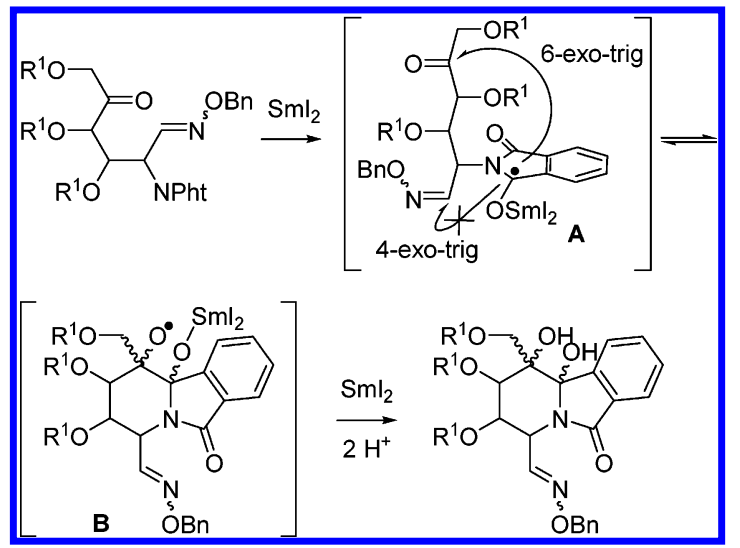

explained postulating that the reaction is initiated by single electron transfer from Sm(II) to the imide ${ }^{16}$ to produce an intermediate ketyl radical-anion A. This radical-anion can then evolve in two different ways: (1) via (reversible) 4-exo-trig addition to the oxime carbon, or (2) via (reversible) 6-exo-trig addition to the ketone carbonyl. It can be reasonably assumed that this last process is much faster than the first and leads to the O-radical anion $\mathbf{B}$, which is then (irreversibly) reduced by $\mathrm{Sm}(\mathrm{II})$ and protonated to yield the final product.

(16) Preferential electron transfer to the imide has been previously proposed by Farcas and Namy ${ }^{6 a}$ for the intermolecular pinacol coupling reaction between $N$-acyl lactams and carbonyl compounds. However, these authors favor the formation of an acyl radical intermediate, which is subsequently reduced to a transient acyl samarium species.
To support our mechanistic proposal, we have performed quantum mechanical DFT calculations on simple model systems representing the different reducible functional groups in our substrates: acetone, $N$-methylphthalimide, and acetaldehyde $O$-methyl-oxime. ${ }^{17}$ Table 2 shows the vertical electron affinity (VEA) and the adiabatic electron affinity (AEA) calculated at the B3LYP/6-311G$(d, p)$ level in the gas phase for the model compounds. ${ }^{22,23}$ The calculated values ${ }^{24}$ show that the phthalimido carbonyl of $N$-methylphthalimide is a much better electronaccepting group than the ketone carbonyl of acetone, the

(17) The relative thermodynamic ease of reduction of the three different $\mathrm{C}=\mathrm{X}(\mathrm{X}=\mathrm{O}, \mathrm{N})$ groups in our substrates might be inferred from available redox potentials for organic molecules containing each of these functional groups. ${ }^{18}$ However, care should be taken when comparing electrochemical data obtained under different experimental conditions due to the sensitivity of the $E_{1 / 2}$ values to solvent, $\mathrm{pH}$, and supporting electrolyte used. The $E_{1 / 2}$ values reported for acetone and for $N$-methylphthalimide are $-2.16 \mathrm{eV}$ (in $\mathrm{H}_{2} \mathrm{O}$ containing $0.01 \mathrm{M} \mathrm{Et}_{4}$ $\mathrm{NI})^{19}$ and $-1.32 \mathrm{eV}$ (in DMF containing $0.5 \mathrm{M} \mathrm{Et}_{4} \mathrm{NClO}_{4}$, value for wave I), ${ }^{20}$ respectively, indicating that the former is less readily reduced. Values reported for oximes and oxime ethers ${ }^{18 \mathrm{~b}}$ are less negative than those above, but correspond to the electroreductive cleavage of the $\mathrm{N}-\mathrm{O}$ bond of the oxime, a process that is not observed under our reaction conditions. Shono et al. ${ }^{21}$ have shown that oxime ethers are not electrochemically reducible under the same conditions as they are coupled to ketones, which led them to propose the intermediacy of ketyl radical-anions for the corresponding electrochemical cross-coupling.

(18) (a) Encyclopedia of Electrochemistry of the Elements; Bard, A J., Lund, H., Eds.; Marcel Dekker: New York, 1979; Vol. 12. (b) Encyclopedia of Electrochemistry of the Elements; Bard, A. J., Lund, H., Eds.; Marcel Dekker: New York, 1984; Vol. 15.

(19) Smirnov, V. A.; Sidorenko, N. F. Gidrokhim. Mater. 1971, 55 126-128 (Chem. Abs. 75: 129147).

(20) Farnia, G.; Romanin, A.; Capobianco, G.; Torzo, F. J. Electroanal. Chem. 1971, 33, 31-44.

(21) Shono, T.; Kise, N.; Fujimoto, T.; Yamanami, A.; Nomura, R. J. Org. Chem. 1994, 59, 1730-1740. 
TABLE 2. Calculated B3LYP/6-311G(d,p) Gas-Phase Vertical Electron Affinities (VEA) and Adiabatic Electron Affinities (AEA) for Acetone, $\boldsymbol{N}$-Methylphthalimide, and Acetaldehyde $O$-Methyl Oxime

\begin{tabular}{lcc}
\hline \multicolumn{1}{c}{ compound } & $\mathrm{VEA}^{a}(\mathrm{eV})$ & $\mathrm{AEA}^{b}(\mathrm{eV})$ \\
\hline acetone & -1.97 & -1.40 \\
$N$-methylphthalimide & 0.52 & 0.78 \\
acetaldehyde $O$-methyl oxime & -2.53 & $-c$
\end{tabular}

${ }^{a}$ VEA values correspond to the energy difference between the optimized neutral molecule and the radical-anion at the geometry of the optimized neutral molecule. ${ }^{b}$ AEA values correspond to the energy difference between the neutral molecule and the radicalanion at their optimized geometries. ${ }^{c}$ The radical-anion is unstable at the UB3LYP/6-311G(d,p) level of theory in the gas phase and dissociates through homolytic cleavage of the $\mathrm{N}-\mathrm{O}$ bond, in parallel with that observed under electrochemical reduction conditions. ${ }^{18 \mathrm{~b}}$

oxime ether being the most difficult to reduce via single electron transfer, in agreement with our mechanistic proposal and with the experimental redox potentials available. ${ }^{19,20}$ However, a note of caution on the interpretation of the quantum mechanical calculations should be added. Our theoretical results are only strictly applicable if the electron transfer is outer-sphere. Yet, recent studies ${ }^{25}$ led to the conclusion that the electron transfer from $\mathrm{SmI}_{2}$ in THF to a ketone carbonyl is an inner-sphere process and the same almost certainly applies to an imide carbonyl. In such a case, the electrontransfer process should be influenced by the nature of the metal-oxygen bond that is being formed during the reaction as well as the energy required for reorganization of the ligands around the metal center on going from oxidation state $2+$ to $3+$.

Two different mechanistic scenarios can be proposed to explain the stereochemical outcome of the cyclization of substrate 8. First, preferential formation of the most stable $(11 \mathrm{~b} R, 11 \mathrm{c} S$ )-isomer (see calculated total energies in Table 1) could be the result of the stereodirecting step being under thermodynamic control, as is implicit in Scheme 5. In an alternative scenario, if the cyclization is under kinetic control, formation of this isomer could

(22) We employed the strategy of using a relatively large basis set but without diffuse functions, which confines the excess electron to the molecular framework allowing relative estimates for molecules with negative valence electron affinities using the DFT method: (a) Li, Y. Cai, Z.; Sevilla, M. D. J. Phys. Chem. A 2002, 106, 1596-1603. (b) Li, P.; Bu, Y.; Ai, H. J. Phys. Chem. A 2004, 108, 1200-1207.

(23) Ab initio calculations were carried out using the Gaussian 98 program package: Frisch, M. J.; Trucks, G. W.; Schlegel, H. B.; Scuseria, G. E.; Robb, M. A.; Cheeseman, J. R.; Zakrzewski, V. G.; Montgomery, J. A., Jr.; Stratmann, R. E.; Burant, J. C.; Dapprich, S.; Millam, J. M.; Daniels, A. D.; Kudin, K. N.; Strain, M. C.; Farkas, O.; Tomasi, J.; Barone, V.; Cossi, M.; Cammi, R.; Mennucci, B.; Pomelli, C.; Adamo, C.; Clifford, S.; Ochterski, J.; Petersson, G. A.; Ayala, P. Y.; Cui, Q.; Morokuma, K.; Malick, D. K.; Rabuck, A. D.; Raghavachari, K.; Foresman, J. B.; Cioslowski, J.; Ortiz, J. V.; Stefanov, B. B.; Liu, G.; Liashenko, A.; Piskorz, P.; Komaromi, I.; Gomperts, R.; Martin, R. L.; Fox, D. J.; Keith, T.; Al-Laham, M. A.; Peng, C. Y.; Nanayakkara A.; Gonzalez, C.; Challacombe, M.; Gill, P. M. W.; Johnson, B.; Chen, W.; Wong, M. W.; Andres, J. L.; Gonzalez, C.; Head-Gordon, M.; Replogle, E. S.; Pople, J. A. Gaussian 98, revision A.3; Gaussian, Inc.: Pittsburgh, PA, 1998.

(24) By convention, a positive EA indicates that the binding reaction of a neutral molecule with an electron is an exoergic process. For a recent review on electron affinity covering theoretical computations, see: Rienstra-Kiracofe, J.; Tschumper, G. S.; Schaefer, H. F., III; Nandi, S.; Ellison, G. B. Chem. Rev. 2002, 102, 231-282.

(25) (a) Miller, R. S.; Sealy, J. M.; Shabangi, M.; Kuhlman, M. L.; Fuchs, J. R.; Flowers, R. A., II. J. Am. Chem. Soc. 2000, 122, 77187722. (b) Enemaerke, R. J.; Daasbjerg. K.; Skrydstrup, T. Chem. Commun. 1999, 343-344.

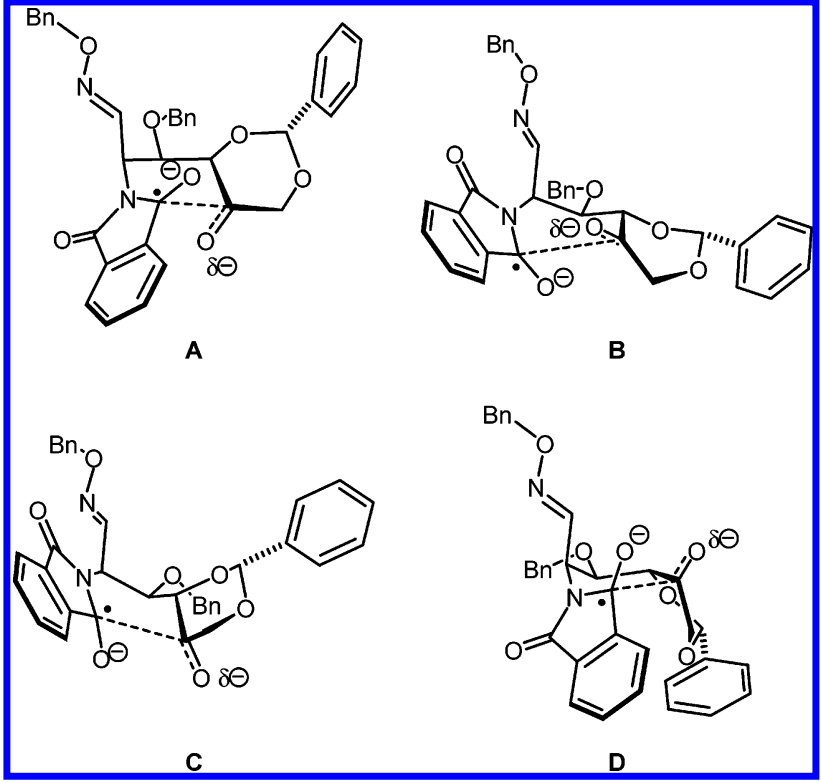

FIGURE 4. Possible transition states for the cyclization of compound $\mathbf{8}$ (for clarity, the metal cation is not shown).

be a consequence of geometrical constraints imposed by the cyclic acetal in the transition state of the $\mathrm{C}-\mathrm{C}$ bondforming step. Figure 4 shows the different transition states that can be proposed for the four possible stereochemical outcomes of the cyclization in this situation. If we assume a late, product-like transition state, equatorial attack of a planar imide radical anion on the ketone carbonyl is geometrically possible for the most stable chair conformation of the benzylidene acetal ring (transition states $\mathbf{A}$ and $\mathbf{C}$ ), while axial attack requires this ring to attain a less stable skew conformation (transition states $\mathbf{B}$ and $\mathbf{D})$. The chairlike transition state $\mathbf{A}$ leading to the observed $(11 \mathrm{~b} R, 11 \mathrm{c} S)$ trans-diol product is expected to be energetically more favorable than the skewlike transition state $\mathbf{C}$, which leads to the alternative $(11 \mathrm{bS}, 11 \mathrm{cS})$ cis-diol. However, in this oversimplified scenario, we have neglected the possible role played by the metal ion. Metal chelation could favor transition state C over A leading to the initial formation of the $(11 \mathrm{~b} S, 11 \mathrm{c} S)$-hemiaminal, which could then equilibrate to the corresponding more stable $(11 \mathrm{~b} R, 11 \mathrm{c} S)$-isomer. The stereochemical outcome observed in this ketone/imide coupling is different from that observed ${ }^{5 d, e, g, 15}$ for the ketone/oxime ether reductive cyclization of closely related systems containing a cyclic ketone, revealing the different mechanisms involved in each case.

Finally, we have performed some simple transformations of tetracycles $\mathbf{1 1}$ to obtain other novel scaffolds that could be useful in diversity-oriented synthesis (Scheme 6). Hydrolysis of the oxime ether and reduction of the resultant aldehyde afforded alcohol 13 in very high yield. This compound was characterized as its corresponding acetyl ester 14. ${ }^{14}$ The ${ }^{1} \mathrm{H}$ NMR chemical shift of the hydroxyl group at C-11b in $\mathbf{1 4}(\delta 5.12 \mathrm{ppm})$ is within the expected range for a hemiaminal hydroxyl, indicating that, at difference with that observed in the case of the acetamido derivative 12, this hydroxyl does not participate in a stable intramolecular hydrogen bond with the ester carbonyl. This fact explains also the absence of cross correlation between $\mathrm{OH}_{11 \mathrm{~b}}$ and the methylenic protons 


\section{SCHEME $6^{a}$}

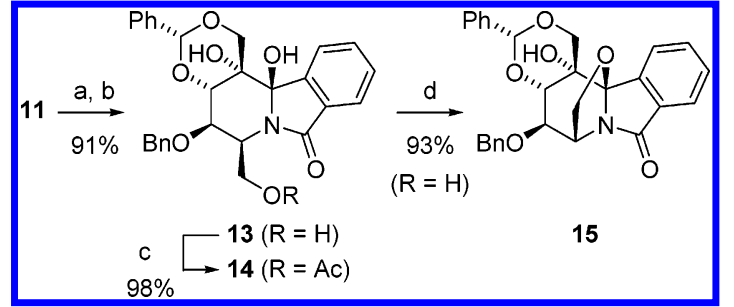

${ }^{a}$ Reagents and conditions: (a) $\mathrm{HCHO}, \mathrm{CSA}, \mathrm{THF} / \mathrm{H}_{2} \mathrm{O}, \mathrm{rt}$; (b) $\mathrm{NaBH}_{4}, \mathrm{MeOH}$, rt; (c) $\mathrm{Ac}_{2} \mathrm{O}$, pyridine, rt; (d) DIAD, $\mathrm{Ph}_{3} \mathrm{P}$, toluene, rt.

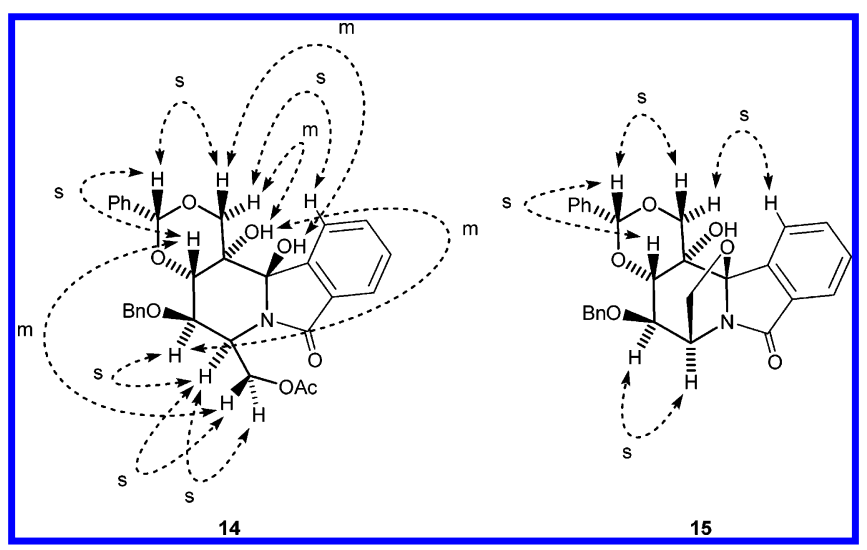

FIGURE 5. Selected NOESY correlations measured for compounds 14 and 15 in $\mathrm{CDCl}_{3}$ at $27{ }^{\circ} \mathrm{C}$.

of the ester side chain at C-6 in the NOESY spectrum (Figure 5). Treatment of $\mathbf{1 3}$ under Mitsunobu conditions provided the rigid pentacyclic scaffold $\mathbf{1 5}^{14}$ in very good yield. The facile formation of $\mathbf{1 5}$ provides a further proof of the $(R)$-stereochemistry at $\mathrm{C}-11 \mathrm{~b}$ in this series of compounds, confirmed by the NOESY spectrum (Figure $5)$.

In summary, we have synthesized a series of novel polyhydroxylated $\alpha$-hydroxylactam scaffolds by an intramolecular ketone/imide pinacol coupling reaction of substrates readily obtained from D-glucosamine. The 6-exo-trig ketone/imide reductive cyclization takes place in preference to an alternative 5-exo-trig ketone/oxime ether coupling. This preference can be rationalized in terms of the very facile single-electron-transfer reduction of $N$-alkylphthalimides as compared to ketones and oxime ethers, as predicted by DFT model calculations. Based on this mechanistic insight, further developments on ketyl radical-anion carbon-carbon bond-forming reactions involving $N$-substituted phthalimides with diverse radicophiles await to be explored. The $\alpha$-hydroxylactam moiety is a precursor for $N$-acyliminium ion chemistry, ${ }^{26}$ which could allow further structural modifications of the scaffold.

\section{Experimental Section}

Compound $1 .{ }^{11}$ To a solution of phenyl 2-deoxy-2-phthalimido-1-thio- $\beta$-D-glucopyranoside ${ }^{27}(500 \mathrm{mg}, 1.39 \mathrm{mmol})$ in $\mathrm{DMF}(5 \mathrm{~mL})$ at $0{ }^{\circ} \mathrm{C}$ were added $\mathrm{BrBn}(1.9 \mathrm{~mL}, 16.68 \mathrm{mmol})$

(26) Maryanoff, B. E.; Zhang, H.-C.; Cohen, J. H.; Turchi, I. J.; Maryanoff, C. A. Chem. Rev. 2004, 104, 1431-1628.

(27) Ogawa, T.; Nakabayashi, S.; Sasajima, K. Carbohydr. Res 1981, $95,308-312$ and $\mathrm{Bu}_{4} \mathrm{NI}(52 \mathrm{mg}, 0.13 \mathrm{mmol})$. To the mixture was added slowly $\mathrm{NaH}$ (60\% dispersion in mineral oil, $251 \mathrm{mg}, 6.27$ $\mathrm{mmol}$ ), and it was stirred at $0{ }^{\circ} \mathrm{C}$ for $30 \mathrm{~min}$ and at $\mathrm{rt}$ for $2 \mathrm{~h}$. The reaction was quenched by addition of $\mathrm{AcOH}$, diluted with $\mathrm{CH}_{2} \mathrm{Cl}_{2}(20 \mathrm{~mL})$, and washed with $\mathrm{H}_{2} \mathrm{O}(3 \times 20 \mathrm{~mL})$. The organic phase was dried over $\mathrm{Na}_{2} \mathrm{SO}_{4}$, concentrated at reduced pressure, and the crude was purified by flash chromatography (hexanes/EtOAc 10:1) to give $\mathbf{1}(675 \mathrm{mg}, 72 \%)$ as a colorless oil. $[\alpha]^{20}{ }_{\mathrm{D}}-1.3\left(c 0.9, \mathrm{CHCl}_{3}\right) ;{ }^{1} \mathrm{H} \mathrm{NMR}\left(300 \mathrm{MHz}, \mathrm{CDCl}_{3}\right) \delta$ 7.78-7.62 (m, 4H), 7.41-7.14 (m, 16H), 7.13-6.81 (m, 4H), $5.53(\mathrm{~d}, 1 \mathrm{H}, J=10.2 \mathrm{~Hz}, \mathrm{H}-1), 4.83\left(\mathrm{~d}, 1 \mathrm{H}, J=11.1 \mathrm{~Hz}, \mathrm{OCH}_{2^{-}}\right.$ $\mathrm{Ph}), 4.77\left(\mathrm{~d}, 1 \mathrm{H}, J=12.0 \mathrm{~Hz}, \mathrm{OCH}_{2} \mathrm{Ph}\right), 4.66(\mathrm{~d}, 1 \mathrm{H}, J=10.8$ $\left.\mathrm{Hz}, \mathrm{OCH}_{2} \mathrm{Ph}\right), 4.64\left(\mathrm{~d}, 1 \mathrm{H}, J=12.0 \mathrm{~Hz}, \mathrm{OCH}_{2} \mathrm{Ph}\right), 4.56(\mathrm{~d}, 1 \mathrm{H}$, $\left.J=11.7 \mathrm{~Hz}, \mathrm{OCH}_{2} \mathrm{Ph}\right), 4.43\left(\mathrm{~d}, 1 \mathrm{H}, J=12.0 \mathrm{~Hz}, \mathrm{OCH}_{2} \mathrm{Ph}\right)$, 4.38 (dd, $1 \mathrm{H}, J=8.1,10.8 \mathrm{~Hz}, \mathrm{H}-2), 4.25$ (t, $1 \mathrm{H}, J=10.5 \mathrm{~Hz}$, $\mathrm{H}-5), 3.88-3.65(\mathrm{~m}, 4 \mathrm{H}) ;{ }^{13} \mathrm{C} \mathrm{NMR}\left(75 \mathrm{MHz} \mathrm{CDCl}_{3}\right) \delta 165.1$, $138.2,137.9,137.7,133.8,132.5,132.0,131.5,129.0,128.7$, $128.4,128.3,128.2,128.0,127.9,127.8,127.7,127.6,127.5$, 127.3, 123.2, 83.2, 80.2, 79.3, 79.3, 74.9, 74.4, 73.3, 68.8, 54.8; MS (ES+) $m / z=694.3\left[\mathrm{M}+\mathrm{Na}^{+}\right]$.

Compound 2. ${ }^{12}$ To a solution of phenyl 2-deoxy-2-phthalimido-1-thio- $\beta$-D-glucopyranoside ${ }^{27}(550 \mathrm{mg}, 1.87 \mathrm{mmol})$ in anhydrous $\mathrm{CH}_{3} \mathrm{CN}(10 \mathrm{~mL})$ was added $\mathrm{PhCH}(\mathrm{OMe})_{2}(1.03 \mathrm{~mL}$, $6.85 \mathrm{mmol}$ ). After stirring at rt for $1 \mathrm{~h}, 0.5 \mathrm{~mL}$ of $\mathrm{Et}_{3} \mathrm{~N}$ was added to give a colorless solution. The mixture was concentrated at reduced pressure, and the crude was purified by flash chromatography (hexanes/EtOAc 3:1) to give the corresponding 4,6-O-benzylidene acetal derivative $(552 \mathrm{mg}, 60 \%)$ as a white solid. Mp $103{ }^{\circ} \mathrm{C} ;[\alpha]_{\mathrm{D}}{ }^{20}-1.9\left(c 2.7, \mathrm{CHCl}_{3}\right) ;{ }^{1} \mathrm{H} \mathrm{NMR}(300 \mathrm{MHz}$, $\left.\mathrm{CDCl}_{3}\right) \delta 7.88-7.83(\mathrm{~m}, 2 \mathrm{H}), 7.75-7.69(\mathrm{~m}, 2 \mathrm{H}), 7.49-7.45(\mathrm{~m}$, $2 \mathrm{H}), 7.40-7.34(\mathrm{~m}, 5 \mathrm{H}), 7.29-7.24(\mathrm{~m}, 3 \mathrm{H}), 5.67(\mathrm{~d}, 1 \mathrm{H}, J=$ $10.5 \mathrm{~Hz}, \mathrm{H}-1), 5.55(\mathrm{~s}, 1 \mathrm{H}), 4.61(\mathrm{ddd}, 1 \mathrm{H}, J=3.9,9.3,10.2$ $\mathrm{Hz}, \mathrm{H}-3$ ), 4.38 (dd, $1 \mathrm{H}, J=4.2,10.5 \mathrm{~Hz}, \mathrm{H}-6), 4.32(\mathrm{t}, 1 \mathrm{H}, J=$ $9.9 \mathrm{~Hz}, \mathrm{H}-2), 3.81(\mathrm{t}, 1 \mathrm{H}, J=9.9 \mathrm{~Hz}, \mathrm{H}-4), 3.64(\mathrm{ddd}, 1 \mathrm{H}, J=$ $5.1,9.3,9.9 \mathrm{~Hz}, \mathrm{H}-5), 3.58$ (t, $1 \mathrm{H}, J=9 \mathrm{~Hz}, \mathrm{H}-6$ ') 2.8 (d, $1 \mathrm{H}$, $J=3.9 \mathrm{~Hz}, \mathrm{OH}) ;{ }^{13} \mathrm{C} \mathrm{NMR}\left(75 \mathrm{MHz}, \mathrm{CDCl}_{3}\right) \delta 168.2,167.4$, $136.8,134.1,132.5,131.7,131.5,131.4,129.3,128.9,128.3$, $128.0,126.2,123.8,123.3,101.8,84.2,81.7,70.2,69.6,68.9$ 55.4; $\mathrm{MS}(\mathrm{ES}+) \mathrm{m} / z=694.2\left[\mathrm{M}+\mathrm{Na}^{+}\right]$.

To a solution of the former benzylidene acetal $(630 \mathrm{mg}, 0.93$ mmol) in anhydrous DMF ( $8 \mathrm{~mL})$ at $0{ }^{\circ} \mathrm{C}$ were added $\mathrm{BrBn}$ (0.34 mL, $2.81 \mathrm{mmol})$ and $\mathrm{Bu}_{4} \mathrm{NI}(35 \mathrm{mg}, 0.09 \mathrm{mmol})$. To the mixture was added slowly $\mathrm{NaH} 60 \%$ (112 $\mathrm{mg}, 2.81 \mathrm{mmol}$ ), and it was stirred at $0{ }^{\circ} \mathrm{C}$ for $30 \mathrm{~min}$ and at $\mathrm{rt}$ for $18 \mathrm{~h}$. The reaction was diluted with $\mathrm{CH}_{2} \mathrm{Cl}_{2}(15 \mathrm{~mL})$ and washed with $\mathrm{H}_{2} \mathrm{O}(3 \times$ $10 \mathrm{~mL}$ ). The organic phase was dried over $\mathrm{Na}_{2} \mathrm{SO}_{4}$, concentrated at reduced pressure, and the crude was purified by flash chromatography (hexanes/EtOAc 6:1) to give 2 (650 mg, 90\%) as a colorless oil. $[\alpha]^{20} \mathrm{D}+4.2\left(c 3.5, \mathrm{CHCl}_{3}\right)$; IR $(\mathrm{KBr}) 3437$, $2862,1774,1714,1382,1095,751,720,699 \mathrm{~cm}^{-1} ;{ }^{1} \mathrm{H}$ NMR $\left(300 \mathrm{MHz}, \mathrm{CDCl}_{3}\right) \delta 8.00-7.27(\mathrm{~m}, 15 \mathrm{H}), 7.12-6.81(\mathrm{~m}, 4 \mathrm{H})$, $5.65(\mathrm{~s}, 1 \mathrm{H}), 5.64(\mathrm{~d}, 1 \mathrm{H}, J=10.2 \mathrm{~Hz}, \mathrm{H}-1), 4.78(\mathrm{~d}, 1 \mathrm{H}, J=$ $\left.12.4 \mathrm{~Hz}, \mathrm{OCH}_{2} \mathrm{Ph}\right), 4.57-4.39(\mathrm{~m}, 3 \mathrm{H}), 4.30(\mathrm{t}, 1 \mathrm{H}, J=10 \mathrm{~Hz}$, $\mathrm{H}-6), 3.90-3.65(\mathrm{~m}, 3 \mathrm{H}) ;{ }^{13} \mathrm{C} \mathrm{NMR}\left(75 \mathrm{MHz}, \mathrm{CDCl}_{3}\right) \delta 167.6$, $167.1,137.5,137.1,133.9,133.8,132.6,131.5,131.4,128.9$, $128.8,128.2,128.0,128.0,127.9,127.3,125.9,123.4,123.3$, $123.3,101.2,84.0,82.7,75.3,74.1,70.2,68.5,54.6 . \mathrm{MS}(\mathrm{ES}+)$ $\mathrm{m} / z=580.1\left[\mathrm{M}+\mathrm{H}^{+}\right]$

Compound 3. To a solution of $1(680 \mathrm{mg}, 0.89 \mathrm{mmol})$ in acetone $(7 \mathrm{~mL})$ and $\mathrm{H}_{2} \mathrm{O}(0.7 \mathrm{~mL})$ at $-15{ }^{\circ} \mathrm{C}$ was added NBS (794 mg, $4.46 \mathrm{mmol}$ ). After being stirred at $-15^{\circ} \mathrm{C}$ for $1 \mathrm{~h}$, the yellow solution was diluted with $\mathrm{CH}_{2} \mathrm{Cl}_{2}(10 \mathrm{~mL})$ and washed with a saturated aqueous solution of $\mathrm{NaHCO}_{3}(2 \times$ $10 \mathrm{~mL}$ ). The phases were separated, and the organic phase was washed with an aqueous $10 \%$ solution of $\mathrm{Na}_{2} \mathrm{~S}_{2} \mathrm{O}_{3}(2 \times 10$ $\mathrm{mL})$ and brine $(2 \times 10 \mathrm{~mL})$ and dried over $\mathrm{Na}_{2} \mathrm{SO}_{4}$. After concentration at reduced pressure, the crude was purified by flash chromatography (hexanes/EtOAc 3:1) to give 3 (450 mg, $99 \%)$ as a colorless oil. $[\alpha]_{\mathrm{D}^{20}}+0.6\left(c 1.5, \mathrm{CHCl}_{3}\right) ;{ }^{1} \mathrm{H}$ NMR $(300$ $\left.\mathrm{MHz} \mathrm{CDCl}_{3}\right) \delta 7.71-7.65(\mathrm{~m}, 4 \mathrm{H}), 7.39-7.18(\mathrm{~m}, 11 \mathrm{H}), 7.09-$ $6.84(\mathrm{~m}, 4 \mathrm{H}), 5.36(\mathrm{t}, 1 \mathrm{H}, J=7.5 \mathrm{~Hz}, \mathrm{H}-1), 4.82(\mathrm{~d}, 1 \mathrm{H}, J=$ $\left.9.9 \mathrm{~Hz}, \mathrm{OCH}_{2} \mathrm{Ph}\right), 4.79\left(\mathrm{~d}, 1 \mathrm{H}, J=11.4 \mathrm{~Hz}, \mathrm{OCH}_{2} \mathrm{Ph}\right), 4.63(\mathrm{~d}$, 
$\left.1 \mathrm{H}, J=12.3 \mathrm{~Hz}, \mathrm{OCH}_{2} \mathrm{Ph}\right), 4.60\left(\mathrm{~d}, 1 \mathrm{H}, J=10.8 \mathrm{~Hz}, \mathrm{OCH}_{2-}\right.$ $\mathrm{Ph}), 4.54\left(\mathrm{~d}, 1 \mathrm{H}, J=12 \mathrm{~Hz}, \mathrm{OCH}_{2} \mathrm{Ph}\right), 4.44(\mathrm{~d}, 1 \mathrm{H}, J=12.0$ $\left.\mathrm{Hz}, \mathrm{OCH}_{2} \mathrm{Ph}\right), 4.42(\mathrm{t}, 1 \mathrm{H}, J=8.1 \mathrm{~Hz}, \mathrm{H}-3), 4.15-4.08(\mathrm{~m}$, $2 \mathrm{H}), 3.79-3.67(\mathrm{~m}, 3 \mathrm{H}), 3.43-3.41(\mathrm{bs}, 1 \mathrm{H}, \mathrm{OH}) ;{ }^{13} \mathrm{C}$ NMR $(75$ $\left.\mathrm{MHz} \mathrm{CDCl}_{3}\right) \delta 168.0,137.9,137.7,133.7,131.5,128.6,128.4$, 128.0,127.9, 127.8, 127.7, 127.3, 126.8, 123.2, 92.8, 80.2, 79.4, $78.8,74.8,74.7,73.5,68.4,57.5$; MS (ES+) $m / z=602.1[\mathrm{M}+$ $\left.\mathrm{Na}^{+}\right]$.

Compound 4. To a solution of $2(160 \mathrm{mg}, 0.21 \mathrm{mmol})$ in acetone $(2 \mathrm{~mL})$ and $\mathrm{H}_{2} \mathrm{O}(0.2 \mathrm{~mL})$ at $-15{ }^{\circ} \mathrm{C}$ was added NBS (187 mg, $1.05 \mathrm{mmol}$ ). After being stirred at $-15^{\circ} \mathrm{C}$ for $1 \mathrm{~h}$, the yellow solution was diluted with $\mathrm{CH}_{2} \mathrm{Cl}_{2}(15 \mathrm{~mL})$ and washed with an aqueous solution of $\mathrm{NaHCO}_{3}(3 \times 15 \mathrm{~mL})$. The combined organic phases were washed with an aqueous $10 \%$ solution of $\mathrm{Na}_{2} \mathrm{~S}_{2} \mathrm{O}_{3}(3 \times 15 \mathrm{~mL})$ followed by brine $(3 \times$ $15 \mathrm{~mL}$ ). After being dried over $\mathrm{Na}_{2} \mathrm{SO}_{4}$, the mixture was concentrated at reduced pressure, and the crude was purified by flash chromatography (hexanes/EtOAc 4:1) to give 4 (94 $\mathrm{mg}, 97 \%)$ as a white solid. Mp $116-118^{\circ} \mathrm{C} ;[\alpha]_{\mathrm{D}}{ }^{20}-1.4(c 1.6$, $\left.\mathrm{CHCl}_{3}\right)$; IR $(\mathrm{KBr}) v_{\max }=3437,2942,1747,1717,1386,1228$, $1073,1038,720 \mathrm{~cm}^{-1}$; ${ }^{1} \mathrm{H} \mathrm{NMR}\left(300 \mathrm{MHz}, \mathrm{CDCl}_{3}\right) \delta 7.74-7.60$ $(\mathrm{m}, 4 \mathrm{H}), 7.53-7.47(\mathrm{~m}, 2 \mathrm{H}), 7.42-7.32(\mathrm{~m}, 4 \mathrm{H}), 7.05-6.80(\mathrm{~m}$, $4 \mathrm{H}), 5.62(\mathrm{~s}, 1 \mathrm{H}, \mathrm{H}-7), 5.49(\mathrm{dd}, 1 \mathrm{H}, J=6.3,8.1 \mathrm{~Hz}, \mathrm{H}-1), 4.81$ $\left(\mathrm{d}, 1 \mathrm{H}, J=12.3 \mathrm{~Hz}, \mathrm{OCH}_{2} \mathrm{Ph}\right), 4.51\left(\mathrm{~d}, 1 \mathrm{H}, J=12.3 \mathrm{~Hz}, \mathrm{OCH}_{2^{-}}\right.$ $\mathrm{Ph}), 4.51$ (dd, $1 \mathrm{H}, J=9,10.2 \mathrm{~Hz}, \mathrm{H}-3), 4.40$ (dd, $1 \mathrm{H}, J=4.8$, $10.8 \mathrm{~Hz}, \mathrm{H}-6$ ), 4.15 (dd, $1 \mathrm{H}, J=8.7,10.2 \mathrm{~Hz}, \mathrm{H}-2), 3.83$ (dd, $\left.2 \mathrm{H}, J=9.9,10.2 \mathrm{~Hz}, \mathrm{H}-4, \mathrm{H}-6^{\prime}\right), 3.69$ (ddd, $1 \mathrm{H}, J=4.8,9.9$, $10.2 \mathrm{~Hz}, \mathrm{H}-5), 3.30(\mathrm{~d}, 1 \mathrm{H}, J=8.1 \mathrm{~Hz}, \mathrm{OH}) ;{ }^{13} \mathrm{C}$ NMR $(75 \mathrm{MHz}$, $\left.\mathrm{CDCl}_{3}\right) \delta 168.0,137.8,137.2,133.9,131.5,129.0,128.3,128.0$ 127.4, 126.0, 123.4, 101.3, 93.4, 83.0, 74.3, 74.1, 68.6, 66.2, 57.6; MS (ES+) $m / z=488.1\left[\mathrm{M}+\mathrm{H}^{+}\right], 510.1\left[\mathrm{M}+\mathrm{Na}^{+}\right]$.

Compound 5. To a solution of $3(132 \mathrm{mg}, 0.22 \mathrm{mmol})$ in $\mathrm{MeOH}(2 \mathrm{~mL})$ were added $O$-benzylhydroxylamine $(130 \mathrm{mg}$, $0.81 \mathrm{mmol})$ and pyridine $(0.16 \mathrm{~mL}, 2.04 \mathrm{mmol})$, and the mixture was heated at reflux for $3 \mathrm{~h}$. After concentration at reduced pressure, the crude was purified by flash chromatography (hexanes/EtOAc 3:1) to afford $\mathbf{5}$ as a colorless oil, mixture of $E$ and $Z$ oximes 3:1 (137 mg, 92\%). IR (KBr) $v_{\max }=$ $3470,2923,1713,1386,1088,1027,737,721,697 \mathrm{~cm}^{-1} ;{ }^{1} \mathrm{H}$ NMR $\left(300 \mathrm{MHz}, \mathrm{CDCl}_{3}\right) \delta 7.84-7.82(\mathrm{~d}, 0.75 \mathrm{H}, J=7.8 \mathrm{~Hz}$, $\mathrm{H}-1 E), 7.77-7.60(\mathrm{~m}, 4 \mathrm{H}), 7.37-7.18(\mathrm{~m}, 13.25 \mathrm{H}), 7.09-6.84$ $(\mathrm{m}, 7 \mathrm{H}), 5.86(\mathrm{dd}, 0.25 \mathrm{H}, J=6.3,10.2 \mathrm{~Hz}, \mathrm{H}-3 Z), 5.42(\mathrm{dd}$, $0.75 \mathrm{H}, J=7.8,10.5 \mathrm{~Hz}, \mathrm{H}-3 E), 5.01(\mathrm{~s}, 2 \mathrm{H}), 5.00(\mathrm{dd}, 0.75 \mathrm{H}$, $J=3.9,8.1 \mathrm{~Hz}), 4.79(\mathrm{t}, 0.25 \mathrm{H}, J=10.8 \mathrm{~Hz}), 4.71-4.31(\mathrm{~m}$, $6 \mathrm{H}), 4.13-4.04(\mathrm{~m}, 2 \mathrm{H}), 3.84-3.61(\mathrm{~m}, 2 \mathrm{H}), 2.7(\mathrm{bs}, 1 \mathrm{H}, \mathrm{OH})$; ${ }^{13} \mathrm{C} \mathrm{NMR}\left(75 \mathrm{MHz} \mathrm{CDCl}_{3}\right) \delta 167.6,147.8,145.7,138.5,138.0$, $138.0,137.9,137.8,137.7,137.6,137.1,137.0,133.6,131.6$, $131.5,128.6,128.4,128.3,128.2,128.1,128.0,127.9,127.8$, $127.8,127.6,127.5,127.2,123.1,86.7,79.5,79.3,76.2,76.0$, $74.8,74.7,74.6,74.3,73.4,73.3,73.2,70.8,69.8,68.5,66.8$, 52.5, 51.0; $\mathrm{MS}(\mathrm{ES}+) \mathrm{m} / z=685.1\left[\mathrm{M}+\mathrm{H}^{+}\right], 707.1\left[\mathrm{M}+\mathrm{Na}^{+}\right]$.

Compound 6. To a solution of $4(250 \mathrm{mg}, 0.51 \mathrm{mmol})$ in $\mathrm{MeOH}(6 \mathrm{~mL})$ were added $O$-benzylhydroxylamine $(295 \mathrm{mg}$, $1.84 \mathrm{mmol})$ and pyridine $(0.37 \mathrm{~mL}, 4.61 \mathrm{mmol})$, and the mixture was heated at reflux for $3 \mathrm{~h}$. After concentration at reduced pressure, the crude was purified by flash chromatography (hexane/EtOAc 3:1) to give 6 as an oil, mixture of $E$ and $Z$ oximes $3.3: 1(300 \mathrm{mg}, 98 \%)$. (E)-Oxime: $[\alpha]_{\mathrm{D}}{ }^{20}+0.6(c 1.5$, $\mathrm{CHCl}_{3}$ ); IR (KBr) $v_{\max }=3468,2927,1713,1387,1090,1027$, 752, 721, $697 \mathrm{~cm}^{-1} ;{ }^{1} \mathrm{H} \mathrm{NMR}\left(300 \mathrm{MHz}, \mathrm{CDCl}_{3}\right) \delta 7.90(\mathrm{~d}, 1 \mathrm{H}$, $J=7.5 \mathrm{~Hz}, \mathrm{H}-1), 7.76-7.70(\mathrm{~m}, 3 \mathrm{H}), 7.69-7.66(\mathrm{~m}, 2 \mathrm{H}), 7.49-$ $7.46(\mathrm{~m}, 2 \mathrm{H}), 7.33-7.31(\mathrm{~m}, 4 \mathrm{H}), 7.30-7.23(\mathrm{~m}, 4 \mathrm{H}), 7.14-$ $7.10(\mathrm{~m}, 2 \mathrm{H}), 7.09-7.04(\mathrm{~m}, 2 \mathrm{H}), 5.47(\mathrm{dd}, 1 \mathrm{H}, J=7.8,9.6$ $\mathrm{Hz}, \mathrm{H}-2), 5.12$ (s, 1H), $5.04\left(\mathrm{~s}, 2 \mathrm{H}, \mathrm{OCH}_{2} \mathrm{Ph}\right), 4.69$ (dd, $1 \mathrm{H}, J=$ $2.4,9.9 \mathrm{~Hz}, \mathrm{H}-3), 4.60\left(\mathrm{~d}, 1 \mathrm{H}, J=12 \mathrm{~Hz}, \mathrm{OCH}_{2} \mathrm{Ph}\right), 4.52(\mathrm{~d}$, $\left.1 \mathrm{H}, J=11.7 \mathrm{~Hz}, \mathrm{OCH}_{2} \mathrm{Ph}\right), 4.24(\mathrm{dd}, 1 \mathrm{H}, J=5.1,10.5 \mathrm{~Hz}$, H-6), 3.95 (m, 1H, $J=4.8,5.1,9.3,10.2 \mathrm{~Hz}, \mathrm{H}-5), 3.65$ (dd, $1 \mathrm{H}, J=2.1,9.3 \mathrm{~Hz}, \mathrm{H}-4), 3.46(\mathrm{t}, 1 \mathrm{H}, J=10.2 \mathrm{~Hz}, \mathrm{H}-6), 1.69$ $(\mathrm{d}, 1 \mathrm{H}, J=4.8 \mathrm{~Hz}, \mathrm{OH})$. (Z)-Oxime: ${ }^{1} \mathrm{H}$ NMR $(300 \mathrm{MHz}$, $\left.\mathrm{CDCl}_{3}\right) \delta 7.71-7.61(\mathrm{~m}, 4 \mathrm{H}), 7.49-7.42(\mathrm{~m}, 3 \mathrm{H}), 7.30-7.06(\mathrm{~m}$, $13 \mathrm{H}), 5.95(\mathrm{dd}, 1 \mathrm{H}, J=6.2,8.4 \mathrm{~Hz}, \mathrm{H}-2), 5.36(\mathrm{~s}, 1 \mathrm{H}), 5.04(\mathrm{~s}$, $2 \mathrm{H}, \mathrm{OCH}_{2} \mathrm{Ph}$ ), 4.45 (dd, $\left.1 \mathrm{H}, J=2.0,8.2 \mathrm{~Hz}, \mathrm{H}-3\right), 4.22(\mathrm{~d}, 1 \mathrm{H}$,
$\left.J=12 \mathrm{~Hz}, \mathrm{OCH}_{2} \mathrm{Ph}\right), 4.52\left(\mathrm{~d}, 1 \mathrm{H}, J=11.7 \mathrm{~Hz}, \mathrm{OCH}_{2} \mathrm{Ph}\right), 4.24$ $(\mathrm{dd}, 1 \mathrm{H}, J=5.0,10.4 \mathrm{~Hz}, \mathrm{H}-6), 3.88(\mathrm{~m}, 1 \mathrm{H}, J=9.4,10.4$, $10.4 \mathrm{~Hz}, \mathrm{H}-5$ ), 3.71 (dd, $1 \mathrm{H}, J=2.4,9.4 \mathrm{~Hz}, \mathrm{H}-4), 3.50$ (t, $1 \mathrm{H}$, $J=10.4 \mathrm{~Hz}, \mathrm{H}-6) ;{ }^{13} \mathrm{C} \mathrm{NMR}\left(75 \mathrm{MHz}, \mathrm{CDCl}_{3}\right)((E)+(Z)$-Oxime $)$ $\delta 167.7,167.4,149.5,145.2,145.1,137.4,137.3,137.2,137.1$, $137.0,136.9,133.8,133.7,131.6,128.6,128.5,128.3,128.3$, $128.2,128.1,128.0,127.7,127.6,126.1,126.1,123.1,123.2$, 101.4, 101.1, 80.8, 80.5, 76.3, 76.0, 74.2, 74.0, 73.6, 73.4, 70.9, $70.9,61.4,50.6,45.3 ; \mathrm{MS}(\mathrm{ES}+) \mathrm{m} / z=593.1\left[\mathrm{M}+\mathrm{H}^{+}\right], 615.2$ $\left[\mathrm{M}+\mathrm{Na}^{+}\right]$.

Compound 7. To a solution of 5 ( $80 \mathrm{mg}, 0.11 \mathrm{mmol})$ in $\mathrm{CH}_{2^{-}}$ $\mathrm{Cl}_{2}(1.2 \mathrm{~mL})$ was added a solution of Dess-Martin periodinane (75 mg, $0.17 \mathrm{mmol})$ in $\mathrm{CH}_{2} \mathrm{Cl}_{2}(0.5 \mathrm{~mL})$. After being stirred at rt for $2 \mathrm{~h}$, the reaction mixture was diluted with $\mathrm{CH}_{2} \mathrm{Cl}_{2}(10$ $\mathrm{mL})$ and washed with a saturated solution of $\mathrm{NaHCO}_{3}(2 \times$ $10 \mathrm{~mL}$ ). To the organic phase was added a $10 \%$ aqueous solution of $\mathrm{Na}_{2} \mathrm{~S}_{2} \mathrm{O}_{3}(5 \mathrm{~mL})$, and the mixture was vigorously stirred for $10 \mathrm{~min}$. The mixture was extracted with $\mathrm{CH}_{2} \mathrm{Cl}_{2}(2$ $\times 15 \mathrm{~mL}$ ), and the organic phase was dried over anhydrous $\mathrm{Na}_{2} \mathrm{SO}_{4}$, filtered, and concentrated at reduced pressure. The crude was purified by flash chromatography (hexanes/EtOAc $4: 1)$ to give 7 as a colorless oil, $4.7: 1 E / Z$ mixture of oximes (78 mg, 99\%), which was used immediately in the next reaction. IR $(\mathrm{KBr}) v_{\max }=2925,1715,1384,1087,1027,737$, $721,697 \mathrm{~cm}^{-1} ;{ }^{1} \mathrm{H}$ NMR $\left(300 \mathrm{MHz} \mathrm{CDCl}_{3}\right) \delta 7.80-7.67(\mathrm{~m}$, $7 \mathrm{H}), 7.35-7.22(\mathrm{~m}, 14 \mathrm{H}), 7.13-6.89(\mathrm{~m}, 5 \mathrm{H}), 5.30(\mathrm{dd}, 1 \mathrm{H}, J$ $=6.0,8.0 \mathrm{~Hz}), 5.28-4.13(\mathrm{~m}, 11 \mathrm{H}) ; \mathrm{MS}(\mathrm{ES}+) \mathrm{m} / \mathrm{z}=591.1[\mathrm{M}$ $\left.+\mathrm{H}^{+}\right], 613.2\left[\mathrm{M}+\mathrm{Na}^{+}\right]$.

Compound 8. To a solution of $(\mathrm{COCl})_{2}(29.4 \mu \mathrm{L}, 0.33 \mathrm{~mol})$ in THF $(0.2 \mathrm{~mL})$ at $-78^{\circ} \mathrm{C}$ was added DMSO $(47.6 \mu \mathrm{L}, 0.67$ $\mathrm{mmol}$ ). After being stirred at $-78^{\circ} \mathrm{C}$ for $20 \mathrm{~min}$, a solution of $6(90 \mathrm{mg}, 0.15 \mathrm{mmol})$ in THF ( $1 \mathrm{~mL})$ was added dropwise. The reaction mixture was stirred at $-20^{\circ} \mathrm{C}$ for $2 \mathrm{~h}$, and $\mathrm{Et}_{3} \mathrm{~N}(140$ $\mu \mathrm{L}, 1.00 \mathrm{mmol}$ ) was added dropwise. The reaction mixture was allowed to slowly attain $0{ }^{\circ} \mathrm{C}$. After being stirred at $0{ }^{\circ} \mathrm{C}$ for $15 \mathrm{~min}$, the crude was diluted with EtOAc $(15 \mathrm{~mL})$ and washed with an aqueous saturated solution of $\mathrm{NH}_{4} \mathrm{Cl}(2 \times 5 \mathrm{~mL})$. The organic phase was dried over anhydrous $\mathrm{Na}_{2} \mathrm{SO}_{4}$, filtered, and concentrated at reduced pressure to a give $\mathbf{8}$ as a mixture of the $E$ and $Z$ oximes $4: 1$ ( $88 \mathrm{mg}, 99 \%$ ) as a colorless oil, which was used immediately in the next reaction. IR $(\mathrm{KBr}) v_{\max }=$ 2927, 1713, 1388, 1090, 1027, 752, 721, $697 \mathrm{~cm}^{-1} ;{ }^{1} \mathrm{H}$ NMR $\left(300 \mathrm{MHz}, \mathrm{CDCl}_{3}\right) \delta 7.84-7.81(\mathrm{~d}, 0.8 \mathrm{H}, J=6.9 \mathrm{~Hz}, \mathrm{H}-1 \mathrm{E})$, $7.74-6.92(\mathrm{~m}, 19.2 \mathrm{H}, \mathrm{H}-1 \mathrm{Z}), 5.95$ (dd, $0.2 \mathrm{H}, J=6.2,8 \mathrm{~Hz}$, $\mathrm{H}-2 \mathrm{Z}), 5.81$ (s, 0.2H, H-7Z), 5.61 (s, 0.8H, H-7E), 5.42 (dd, 0.8H, $J=7.2,9.6 \mathrm{~Hz}, \mathrm{H}-2 \mathrm{E}), 5.05(\mathrm{~s}, 2 \mathrm{H}), 5.00(\mathrm{~m}, 1 \mathrm{H}), 4.80(\mathrm{dd}$, $0.2 \mathrm{H}, J=1.6,8 \mathrm{~Hz}, \mathrm{H}-3 \mathrm{Z}), 4.6-4.3(\mathrm{~m}, 4.8 \mathrm{H}) ;{ }^{13} \mathrm{C} \mathrm{NMR}(75$ $\left.\mathrm{MHz} \mathrm{CDCl}_{3}\right) \delta 207.3,204.9,168.0,167.9,145.3,144.4,137.6$, $137.5,136.8,133.8,133.8,131.8,131.6,129.1,128.3,128.2$, 128.07, 127.9, 127.5, 126.2, 126.1, 123.2, 99.0, 98.9, 82.1, 82.0, $75.6,75.6,74.9,74.5,74.4,72.6,72.1,71.8,50.6,45.9$.

Compounds 9 and 10. To a $0.1 \mathrm{M}$ solution of $\mathrm{SmI}_{2}$ in $\mathrm{THF}$ $(5.0 \mathrm{~mL}, 0.50 \mathrm{mmol})$ and $t$-BuOH $(81 \mu \mathrm{L}, 0.84 \mathrm{mmol})$ at -30 ${ }^{\circ} \mathrm{C}$ was added dropwise a solution of $7(100 \mathrm{mg}, 0.14 \mathrm{mmol})$ in THF ( $3 \mathrm{~mL})$. After the mixture was stirred at $-30{ }^{\circ} \mathrm{C}$ for $3 \mathrm{~h}$, the flask was opened to air to oxidize excess $\mathrm{SmI}_{2}$, and the crude reaction mixture was filtered through Florisil, eluting with $\mathrm{CH}_{2} \mathrm{Cl}_{2} / \mathrm{MeOH}$ 10:1. The filtrate was evaporated at reduced pressure, and the residue was purified by flash chromatography (hexanes/EtOAc $4: 1)$ to give 9 (45 mg, 44\%) and 10 (34 mg, 34\%) as colorless oils, each as a mixture of diastereoisomers at the new stereocenters. Compound 9 (17:1 mixture of diastereoisomers): $v_{\max }=3369,1681,1454,1364$, 1093, $1024 \mathrm{~cm}^{-1} ;{ }^{1} \mathrm{H}$ NMR $\left(300 \mathrm{MHz}, \mathrm{CDCl}_{3}\right) \delta 7.83(\mathrm{~m}, 1 \mathrm{H})$, $7.72\left(\mathrm{~d}, 1 \mathrm{H}, J=3.9 \mathrm{~Hz}, \mathrm{H}-4^{\prime}\right), 7.63-7.13(\mathrm{~m}, 21 \mathrm{H}), 6.76-6.73$ (m, 2H), 5.46 (dd, 0.95H, $J=4.5,6.6 \mathrm{~Hz}, \mathrm{H}-4_{\text {major }}$ ), 5.35 (dd, $\left.0.05 \mathrm{H}, J=4.5,6.6 \mathrm{~Hz}, \mathrm{H}-4_{\text {minor }}\right), 5.10$ (s, $0.1 \mathrm{H}, \mathrm{NOCH}_{2} \mathrm{Ph}_{\text {minor }}$ ), $5.01\left(\mathrm{~s}, 1.9 \mathrm{H}, \mathrm{NOCH}_{2} \mathrm{Ph}_{\text {major }}\right), 4.89\left(\mathrm{~d}, 1 \mathrm{H}, \mathrm{J}=11.1 \mathrm{~Hz}, \mathrm{OCH}_{2^{-}}\right.$ $\mathrm{Ph}), 4.83\left(\mathrm{~d}, 1 \mathrm{H}, J=11.1 \mathrm{~Hz}, \mathrm{OCH}_{2} \mathrm{Ph}\right), 4.71(\mathrm{~s}, 1 \mathrm{H}, \mathrm{OH}-10 \mathrm{~b})$, $4.69\left(\mathrm{~d}, 1 \mathrm{H}, J=11.1 \mathrm{~Hz}, \mathrm{OCH}_{2} \mathrm{Ph}\right), 4.64(\mathrm{~d}, 1 \mathrm{H}, J=11.1 \mathrm{~Hz}$, $\left.\mathrm{OCH}_{2} \mathrm{Ph}\right), 4.01(\mathrm{~d}, 1 \mathrm{H}, J=12.0 \mathrm{~Hz}), 3.89-3.77(\mathrm{~m}, 2 \mathrm{H}), 3.41$ (s, 1H, OH-1), 3.37 (d, $\left.1 \mathrm{H}, J=9.9 \mathrm{~Hz}, \mathrm{H}-1^{\prime} \mathrm{b}\right), 3.03(\mathrm{~d}, 0.05 \mathrm{H}$, 
$\left.J=9.3 \mathrm{~Hz}, \mathrm{H}-1 \mathrm{a}_{\text {minor }}\right), 2.96\left(\mathrm{~d}, 0.95 \mathrm{H}, J=9.3 \mathrm{~Hz}, \mathrm{H}-1^{\prime} \mathrm{a}_{\text {major }}\right.$ ); ${ }^{13} \mathrm{C} \mathrm{NMR}\left(75 \mathrm{MHz}, \mathrm{CDCl}_{3}\right) \delta 166.8,149.7,145.9,144.7,138.7$, $137.7,136.6,132.3,131.2,130.3,129.4,128.6,128.5,128.4$, $128.2,128.1,127.9,127.7,127.6,127.5,127.3,124.6,123.5$, $123.2,88.7,83.9,81.5,75.3,73.4,73.2,68.4,65.9,62.0,48.6$, 48.1. MS (ES+) $\mathrm{m} / z=685.0\left[\mathrm{M}+\mathrm{H}^{+}\right], 707.0\left[\mathrm{M}+\mathrm{Na}^{+}\right]$. Compound 10 (3.5:1 mixture of diastereoisomers): $v_{\max }=3369$, $1694,1454,1364,1098,1028 \mathrm{~cm}^{-1} ;{ }^{1} \mathrm{H} \mathrm{NMR}\left(300 \mathrm{MHz}, \mathrm{CDCl}_{3}\right)$ $\delta 7.81(\mathrm{~m}, 1 \mathrm{H}), 7.61-7.06\left(\mathrm{~m}, 22 \mathrm{H}, \mathrm{H}-4^{\prime}\right), 6.78-6.75(\mathrm{~m}, 2 \mathrm{H})$, 5.96 (t, $\left.0.77 \mathrm{H}, J=6.9 \mathrm{~Hz}, \mathrm{H}-4_{\text {major }}\right), 5.68$ (t, $0.23 \mathrm{H}, J=6.9$ $\left.\mathrm{Hz}, \mathrm{H}-4_{\text {minor }}\right), 5.10\left(\mathrm{~d}, 1 \mathrm{H}, J=10.8 \mathrm{~Hz}, \mathrm{NOCH}_{2} \mathrm{Ph}\right), 5.05(\mathrm{~d}$, $\left.1 \mathrm{H}, J=10.8 \mathrm{~Hz}, \mathrm{NOCH}_{2} \mathrm{Ph}\right), 4.90\left(\mathrm{~d}, 1 \mathrm{H}, J=11.4 \mathrm{~Hz}, \mathrm{OCH}_{2^{-}}\right.$ $\mathrm{Ph}), 4.85\left(\mathrm{~d}, 1 \mathrm{H}, J=11.1 \mathrm{~Hz}, \mathrm{OCH}_{2} \mathrm{Ph}\right), 4.67(\mathrm{~d}, 1 \mathrm{H}, J=11.7$ $\left.\mathrm{Hz}, \mathrm{OCH}_{2} \mathrm{Ph}\right), 4.53\left(\mathrm{~d}, 1 \mathrm{H}, J=11.7 \mathrm{~Hz}, \mathrm{OCH}_{2} \mathrm{Ph}\right), 4.22(\mathrm{~d}, 1 \mathrm{H}$, $J=10.5 \mathrm{~Hz}, \mathrm{H}-2), 4.02-3.95\left(\mathrm{~m}, 2 \mathrm{H}, \mathrm{H}-3, \mathrm{OCH}_{2} \mathrm{Ph}\right), 3.81(\mathrm{~d}$, $\left.1 \mathrm{H}, J=12.3 \mathrm{~Hz}, \mathrm{OCH}_{2} \mathrm{Ph}\right), 3.56(\mathrm{~d}, 0.23 \mathrm{H}, J=9.3 \mathrm{~Hz}$, $\left.\mathrm{H}-1 \mathrm{~b}_{\text {minor }}\right), 3.22\left(\mathrm{~d}, 0.77 \mathrm{H}, J=9.3 \mathrm{~Hz}, \mathrm{H}-1 \mathrm{~b}_{\text {major }}\right), 3.09(\mathrm{~d}, 0.77 \mathrm{H}$, $\left.J=9.3 \mathrm{~Hz}, \mathrm{H}-1 \mathrm{a}_{\text {major }}\right), 2.99\left(\mathrm{~d}, 0.23 \mathrm{H}, J=9.3 \mathrm{~Hz}, \mathrm{H}-1 \mathrm{a}_{\text {minor }}\right)$; ${ }^{13} \mathrm{C}$ NMR $\left(75 \mathrm{MHz}^{\mathrm{CDCl}} \mathrm{CD}_{3}\right) \delta 163.9,149.7,145.9,143.0,138.7$, $137.7,136.6,132.3,129.4,128.4,128.2$, 127.8, 127.7, 127.6, $127.5,127.3,123.5,123.2,88.7,83.9,81.7,75.3,73.4,73.2,68.4$, $65.9,63.9,48.6$; $\mathrm{MS}(\mathrm{ES}+) \mathrm{m} / z=685.0\left[\mathrm{M}+\mathrm{H}^{+}\right], 707.0[\mathrm{M}+$ $\mathrm{Na}^{+}$.

Compounds $(E)-11$ and $(Z)-11$. To a $0.1 \mathrm{M}$ solution of $\mathrm{SmI}_{2}$ in THF $(5.0 \mathrm{~mL}, 0.50 \mathrm{mmol})$ and $t-\mathrm{BuOH}(81 \mu \mathrm{L}, 0.84 \mathrm{mmol})$ at $-30{ }^{\circ} \mathrm{C}$ was added dropwise a solution of $8(100 \mathrm{mg}, 0.16$ $\mathrm{mmol}$ ) in THF ( $3 \mathrm{~mL}$ ). After the mixture was stirred at -30 ${ }^{\circ} \mathrm{C}$ for $3 \mathrm{~h}$, the flask was opened to air to oxidize excess $\mathrm{SmI}_{2}$, and the crude reaction mixture was filtered through Florisil, eluting with $\mathrm{CH}_{2} \mathrm{Cl}_{2} / \mathrm{MeOH}$ 10:1. The filtrate was evaporated at reduced pressure, and the residue was purified by flash chromatography (hexanes/EtOAc 4:1) to give $(E)-\mathbf{1 1}(45 \mathrm{mg}$, $45 \%)$ and $(Z)-11(25 \mathrm{mg}, 25 \%)$ as colorless oils. $(E)-11:[\alpha]_{\mathrm{D}}{ }^{20}$ $+3.1\left(c 0.8, \mathrm{CHCl}_{3}\right)$; IR (KBr) $v_{\max }=3429,1697 \mathrm{~cm}^{-1} ;{ }^{1} \mathrm{H}$ NMR $\left(300 \mathrm{MHz} \mathrm{CDCl}_{3}\right) \delta 7.91\left(\mathrm{~d}, 1 \mathrm{H}, J=4.2 \mathrm{~Hz}, \mathrm{H}-6^{\prime}\right), 7.81(\mathrm{~d}$, $1 \mathrm{H}, J=7.4 \mathrm{~Hz}, \mathrm{H}-8), 7.6-7.3(\mathrm{~m}, 18 \mathrm{H}), 5.71(\mathrm{dd}, 1 \mathrm{H}, J=4.1$, $7.5 \mathrm{~Hz}, \mathrm{H}-6), 5.68$ (s, 1H, H-3), 5.41 (s, 1H, OH-11b), 5.06 (d, $\left.1 \mathrm{H}, J=11.7 \mathrm{~Hz}, \mathrm{NOCH}_{2} \mathrm{Ph}\right), 5.03\left(\mathrm{~d}, 1 \mathrm{H}, J=11.7 \mathrm{~Hz}, \mathrm{NOCH}_{2^{-}}\right.$ $\mathrm{Ph}), 4.80\left(\mathrm{~d}, 1 \mathrm{H}, J=11.7 \mathrm{~Hz}, \mathrm{OCH}_{2} \mathrm{Ph}\right), 4.68(\mathrm{~d}, 1 \mathrm{H}, J=11.7$ $\mathrm{Hz}, \mathrm{OCH}_{2} \mathrm{Ph}$ ), 4.58 (d, $\left.1 \mathrm{H}, J=11.3 \mathrm{~Hz}, \mathrm{H}-1 \mathrm{~b}\right), 4.54$ (d, $1 \mathrm{H}, J$ $=9.8 \mathrm{~Hz}, \mathrm{H}-4 \mathrm{a}), 4.30(\mathrm{~d}, 1 \mathrm{H}, J=11.3 \mathrm{~Hz}, \mathrm{H}-1 \mathrm{a}), 4.21(\mathrm{dd}, 1 \mathrm{H}$, $J=7.5,9.6 \mathrm{~Hz}, \mathrm{H}-5), 2.83$ (s, $1 \mathrm{H}, \mathrm{OH}-11 \mathrm{c}) ;{ }^{13} \mathrm{C} \mathrm{NMR}(75 \mathrm{MHz}$, $\left.\mathrm{CDCl}_{3}\right) \delta 166.8,149.7,144.6,137.6,137.1,136.4,132.6,130.6$, $129.7,129.1,128.5,128.5,128.4,128.2,128.2,127.9,127.6$, 125.7, 123.9, 122.0, 118.3, 101.8 (C-3), $88.6(\mathrm{C}-11 \mathrm{~b}), 78.1(\mathrm{C}-$ 4a), $76.3\left(\mathrm{NOCH}_{2} \mathrm{Ph}\right), 74.0\left(\mathrm{OCH}_{2} \mathrm{Ph}\right), 73.8(\mathrm{C}-5), 71.5(\mathrm{C}-1)$, 70.7 (C-11c), 49.1 (C-6). Anal. Calcd for $\mathrm{C}_{35} \mathrm{H}_{32} \mathrm{~N}_{2} \mathrm{O}_{7}$ : C, 70.93; $\mathrm{H}, 5.44 ; \mathrm{N}, 4.73$. Found: C, 70.78; H, 5.60; N, 4.67. (Z)-11: $[\alpha]_{\mathrm{D}}{ }^{20}-2.5\left(c \quad 0.6, \mathrm{CHCl}_{3}\right) ; \mathrm{IR}(\mathrm{KBr}) v_{\max }=3429,1710 \mathrm{~cm}^{-1}$; ${ }^{1} \mathrm{H} \mathrm{NMR}\left(300 \mathrm{MHz}, \mathrm{CDCl}_{3}\right) \delta 7.9-6.94(\mathrm{~m}, 19 \mathrm{H}), 7.38(\mathrm{~d}, 1 \mathrm{H}$, $\left.J=5.6 \mathrm{~Hz}, \mathrm{H}-6^{\prime}\right), 5.89(\mathrm{dd}, 1 \mathrm{H}, J=5.6,6.8 \mathrm{~Hz}, \mathrm{H}-6), 5.72(\mathrm{~s}$, $1 \mathrm{H}, \mathrm{H}-3), 5.03\left(\mathrm{~d}, 1 \mathrm{H}, J=11.6 \mathrm{~Hz}, \mathrm{NOCH}_{2} \mathrm{Ph}\right), 4.99(\mathrm{~d}, 1 \mathrm{H}, J$ $\left.=12.0 \mathrm{~Hz}, \mathrm{NOCH}_{2} \mathrm{Ph}\right), 4.68(\mathrm{~d}, 1 \mathrm{H}, J=9.6 \mathrm{~Hz}, \mathrm{H}-4 \mathrm{a}), 4.66(\mathrm{~s}$, $\left.2 \mathrm{H}, \mathrm{OCH}_{2} \mathrm{Ph}\right), 4.50(\mathrm{~d}, 1 \mathrm{H}, J=10.8 \mathrm{~Hz}, \mathrm{H}-1 \mathrm{~b}), 4.17(\mathrm{~d}, 1 \mathrm{H}, J$ $=11.2 \mathrm{~Hz}, \mathrm{H}-1 \mathrm{a}), 4.07(\mathrm{dd}, 1 \mathrm{H}, J=6.8,10.0 \mathrm{~Hz}, \mathrm{H}-5), 2.87(\mathrm{~s}$, $1 \mathrm{H}, \mathrm{OH}-11 \mathrm{c}) ;{ }^{13} \mathrm{C} \mathrm{NMR}\left(75 \mathrm{MHz}, \mathrm{CDCl}_{3}\right) \delta 164.8,147.6\left(\mathrm{C}-6^{\prime}\right)$, $142.8,137.7,137.0,132.1,130.2,129.1,128.5,128.3,128.2$, $128.1,127.8,127.7,127.6,125.8,123.8,121.9,101.5(\mathrm{C}-3), 89.3$ (C-11b), $78.1(\mathrm{C}-4 \mathrm{a}), 76.2\left(\mathrm{NOCH}_{2} \mathrm{Ph}\right), 73.2\left(\mathrm{OCH}_{2} \mathrm{Ph}\right), 72.5(\mathrm{C}-$ 5), $71.4(\mathrm{C}-1), 70.1$ (C-11c), $43.6(\mathrm{C}-6)$; MS (ES+) $\mathrm{m} / \mathrm{z}=593.3$ $\left[\mathrm{M}+\mathrm{H}^{+}\right], 615.3\left[\mathrm{M}+\mathrm{Na}^{+}\right]$.

Compound 12. To a $0.1 \mathrm{M}$ solution of $\mathrm{SmI}_{2}(10.0 \mathrm{~mL}, 1.0$ $\mathrm{mmol})$ in $\mathrm{THF}$ and $t \mathrm{BuOH}(0.162 \mathrm{~mL}, 1.69 \mathrm{mmol})$ at $-30{ }^{\circ} \mathrm{C}$ was added dropwise a solution of $8(90 \mathrm{mg}, 0.15 \mathrm{mmol})$ in THF $(3 \mathrm{~mL})$. After the mixture was stirred at $-30^{\circ} \mathrm{C}$ for $3 \mathrm{~h}$, water was added $(60.8 \mu \mathrm{L}, 3.38 \mathrm{mmol})$, and the reaction mixture was stirred at rt overnight. The flask was opened to air to oxidize excess $\mathrm{SmI}_{2}$, and pyridine $(0.79 \mathrm{~mL}, 0.98 \mathrm{mmol})$ and $\mathrm{Ac}_{2} \mathrm{O}(0.4$ $\mathrm{mL}, 0.36 \mathrm{mmol}$ ) were added. After the mixture was stirred for $2 \mathrm{~h}$ at $\mathrm{rt}$, saturated aqueous $\mathrm{NaHCO}_{3}(10 \mathrm{~mL})$ was added, and the mixture was extracted with EtOAc $(3 \times 10 \mathrm{~mL})$. The combined organic layers were washed with brine $(3 \times 10 \mathrm{~mL})$, dried over $\mathrm{Na}_{2} \mathrm{SO}_{4}$, and the solvent was removed at reduced pressure. The crude was purified by flash chromatography (hexanes/EtOAc 3:1) to give $\mathbf{1 2}(52 \mathrm{mg}, 65 \%)$ as a light yellow oil. $[\alpha]_{\mathrm{D}}{ }^{20}-3.7\left(c 0.2, \mathrm{CHCl}_{3}\right)$; IR (KBr) $v_{\max }=3340,1731,1682$ $\mathrm{cm}^{-1} ;{ }^{1} \mathrm{H} \mathrm{NMR}\left(300 \mathrm{MHz}, \mathrm{CDCl}_{3}\right) \delta 7.72(\mathrm{~d}, 1 \mathrm{H}, J=7.6 \mathrm{~Hz})$, $7.57-7.25$ (m, 14H, OH-11b), 6.15 (br dd, $1 \mathrm{H}, J=4.5,9.9 \mathrm{~Hz}$, $\mathrm{NH}), 5.81$ (s, 1H, H-3), 4.91 (d, 1H, $J=9.9 \mathrm{~Hz}, \mathrm{H}-4 \mathrm{a}), 4.82$ (d, $1 \mathrm{H}, J=11.7 \mathrm{~Hz}, \mathrm{OCH}_{2} \mathrm{Ph}$ ), 4.78 (ddd, $1 \mathrm{H}, J=3.9,7.5,10.8$ $\mathrm{Hz}, \mathrm{H}-6), 4.74(\mathrm{~d}, 1 \mathrm{H}, J=11.1 \mathrm{~Hz}, \mathrm{H}-1 \mathrm{~b}), 4.64(\mathrm{~d}, 1 \mathrm{H}, J=$ $11.7 \mathrm{~Hz}, \mathrm{OCH}_{2} \mathrm{Ph}$ ), 4.36 (ddd, $1 \mathrm{H}, J=9.9,10.8,14.4 \mathrm{~Hz}, \mathrm{H}-6{ }^{\prime} \mathrm{a}$ ), $4.31(\mathrm{~d}, 1 \mathrm{H}, J=11.1 \mathrm{~Hz}, \mathrm{H}-1 \mathrm{a}), 4.15(\mathrm{~d}, 1 \mathrm{H}, J=7.5,9.9 \mathrm{~Hz}$, $\mathrm{H}-5$ ), 3.43 (dt, $1 \mathrm{H}, J=3.9,4.1,14.4 \mathrm{~Hz}, \mathrm{H}-6$ 'b), 2.90 (s, $1 \mathrm{H}$, $\mathrm{OH}-11 \mathrm{c}), 1.83\left(\mathrm{~s}, 3 \mathrm{H}, \mathrm{CH}_{3} \mathrm{CO}\right) ;{ }^{13} \mathrm{C} \mathrm{NMR}\left(75 \mathrm{MHz}, \mathrm{CDCl}_{3}\right) \delta$ $173.2,167.6,149.7,138.0,137.3,132.4,131.0,129.5,129.0$, 128.4, 128.2, 127.8, 127.6, 125.8, 123.4, 122.4, $101.4(\mathrm{C}-3), 89.6$ (C-11b), $78.6(\mathrm{C}-4 \mathrm{a}), 74.2\left(\mathrm{OCH}_{2} \mathrm{Ph}\right), 73.7(\mathrm{C}-5), 71.7(\mathrm{C}-1), 70.8$ (C-11c), 50.5 (C-6), $39.2\left(\mathrm{C}^{\prime} 6^{\prime}\right), 23.2\left(\mathrm{CH}_{3} \mathrm{CO}\right) ; \mathrm{MS}(\mathrm{ES}+) \mathrm{m} / \mathrm{z}$ $=553.2\left[\mathrm{M}+\mathrm{Na}^{+}\right]$

Compound 13. To a solution of $\mathbf{1 1}$ (151 mg, $0.25 \mathrm{mmol})$ in THF $(2 \mathrm{~mL})$ was added dropwise a $37 \%$ solution of formaldehyde in water $(15 \mathrm{~mL}, 25.9 \mathrm{mmol})$, and the mixture was stirred for $16 \mathrm{~h}$ at rt. After dilution with EtOAc $(10 \mathrm{~mL})$, the organic phase was washed with a saturated aqueous solution of $\mathrm{NaHCO}_{3}(3 \times 10 \mathrm{~mL})$, brine $(2 \times 10 \mathrm{~mL})$, and dried over $\mathrm{Na}_{2-}$ $\mathrm{SO}_{4}$. The mixture was concentrated at reduced pressure, and the crude was dissolved in THF/MeOH $(1: 1,4 \mathrm{~mL})$. To this solution was added $\mathrm{NaBH}_{4}(236 \mathrm{mg}, 1.01 \mathrm{mmol})$ at $0{ }^{\circ} \mathrm{C}$, and the mixture was stirred for $1 \mathrm{~h}$ at $0{ }^{\circ} \mathrm{C}$ and for $16 \mathrm{~h}$ at rt. After dilution with EtOAc $(10 \mathrm{~mL})$, the organic phase was washed with $\mathrm{H}_{2} \mathrm{O}(3 \times 10 \mathrm{~mL})$, brine $(2 \times 10 \mathrm{~mL})$, dried over $\mathrm{Na}_{2} \mathrm{SO}_{4}$, and concentrated at reduced pressure. The crude was purified by flash chromatography (hexanes/EtOAc 3:1) to give 13 (112 $\mathrm{mg}, 91 \%)$ as a white solid. $\mathrm{Mp} 185-187^{\circ} \mathrm{C} ;[\alpha]_{\mathrm{D}}{ }^{25}+5.2(c 0.4$, $\left.\mathrm{CHCl}_{3}\right) ;{ }^{1} \mathrm{H}$ NMR $\left(400 \mathrm{MHz}, \mathrm{CDCl}_{3}\right) \delta 7.70(\mathrm{~d}, 2 \mathrm{H}), 7.60-7.27$ $(\mathrm{m}, 12 \mathrm{H}), 5.78$ (s, 1H, H-3), 5.65 (s, 1H, OH-11b), 4.96 (ddd, $1 \mathrm{H}, J=3.5,4.9,8.5 \mathrm{~Hz}, \mathrm{H}-6), 4.86(\mathrm{~d}, 1 \mathrm{H}, J=9.7 \mathrm{~Hz}, \mathrm{H}-4 \mathrm{a})$, $4.81\left(\mathrm{~d}, 1 \mathrm{H}, J=11.6 \mathrm{~Hz}, \mathrm{OCH}_{2} \mathrm{Ph}\right), 4.71(\mathrm{~d}, 1 \mathrm{H}, J=11.7 \mathrm{~Hz}$, $\left.\mathrm{OCH}_{2} \mathrm{Ph}\right), 4.66(\mathrm{~d}, 1 \mathrm{H}, J=11.2 \mathrm{~Hz}, \mathrm{H}-1 \mathrm{~b}), 4.33(\mathrm{~d}, 1 \mathrm{H}, J=$ $11.1 \mathrm{~Hz}, \mathrm{H}-1 \mathrm{a}$ ), 4.27 (dd, $1 \mathrm{H}, J=5.1,11.3 \mathrm{~Hz}, \mathrm{H}-6$ 'b), 4.18 $(\mathrm{dd}, 1 \mathrm{H}, J=7.7,9.6 \mathrm{~Hz}, \mathrm{H}-5), 3.91(\mathrm{dd}, 1 \mathrm{H}, J=3.8,11.3 \mathrm{~Hz}$, H-6'a), 3.04 (m, 1H, OH-6'), 2.91 (s, $1 \mathrm{H}, \mathrm{OH}-11 \mathrm{c}) ;{ }^{13} \mathrm{C}$ NMR $\left(100 \mathrm{MHz}, \mathrm{CDCl}_{3}\right) \delta 168.5,140.4,137.7,136.9,133.8,132.8$, $130.7,129.2,128.5,128.3,127.9,127.6,125.8,125.0,123.0$, 102.5 (C-3), $97.0(\mathrm{C}-11 \mathrm{~b}), 82.0(\mathrm{C}-4 \mathrm{a}), 75.2(\mathrm{C}-5), 72.9\left(\mathrm{OCH}_{2-}\right.$ $\mathrm{Ph}), 71.7(\mathrm{C}-1), 71.6\left(\mathrm{C}-6^{\prime}\right), 71.6(\mathrm{C}-11 \mathrm{c}), 52.7(\mathrm{C}-6)$; MS (ES+) $m / z=512.3\left[\mathrm{M}+\mathrm{Na}^{+}\right]$

Compound 14. To a solution of $13(33 \mathrm{mg}, 0.06 \mathrm{mmol})$ in anhydrous pyridine $(0.3 \mathrm{~mL})$ was added $\mathrm{Ac}_{2} \mathrm{O}(7.62 \mu \mathrm{L}, 0.08$ mmol). After being stirred for $5 \mathrm{~h}$ at rt, the mixture was concentrated at reduced pressure, and the crude was purified by flash chromatography (hexanes/EtOAc 3:1) to give 14 (34 mg, $98 \%)$ as a colorless oil. $[\alpha]_{\mathrm{D}}{ }^{25}+10.6\left(c 0.1, \mathrm{CHCl}_{3}\right) ;{ }^{1} \mathrm{H}$ NMR $\left(400 \mathrm{MHz}, \mathrm{CDCl}_{3}\right) \delta 7.78(\mathrm{~d}, 1 \mathrm{H}, J=6.8 \mathrm{~Hz}), 7.60-7.25(\mathrm{~m}$, $13 \mathrm{H}), 5.80$ (s, $1 \mathrm{H}, \mathrm{H}-3), 5.22\left(\mathrm{dd}, 1 \mathrm{H}, J=10.8,11.6 \mathrm{~Hz}, \mathrm{H}-6^{\prime} \mathrm{b}\right)$, 5.12 (s, 1H, OH-11b), 5.07 (ddd, $1 \mathrm{H}, J=3.2,7.2,10.8 \mathrm{~Hz}, \mathrm{H}-6$ ), $4.83(\mathrm{~d}, 1 \mathrm{H}, J=9.6 \mathrm{~Hz}, \mathrm{H}-4 \mathrm{a}), 4.82\left(\mathrm{~d}, 1 \mathrm{H}, J=11.6 \mathrm{~Hz}, \mathrm{OCH}_{2^{-}}\right.$ $\mathrm{Ph}), 4.73\left(\mathrm{~d}, 1 \mathrm{H}, J=11.6 \mathrm{~Hz}, \mathrm{OCH}_{2} \mathrm{Ph}\right), 4.70(\mathrm{~d}, 1 \mathrm{H}, J=11.2$ $\mathrm{Hz}, \mathrm{H}-1 \mathrm{~b}), 4.40$ (dd, $\left.1 \mathrm{H}, J=3.2,11.6 \mathrm{~Hz}, \mathrm{H}-6^{\prime} \mathrm{a}\right), 4.31$ (d, $1 \mathrm{H}$ $J=11.2 \mathrm{~Hz}, \mathrm{H}-1 \mathrm{a}), 4.18$ (dd, $1 \mathrm{H}, J=7.6,10.0 \mathrm{~Hz}, \mathrm{H}-5), 2.88$ (s, $1 \mathrm{H}, \mathrm{OH}-11 \mathrm{c}), 1.99\left(\mathrm{~s}, 3 \mathrm{H}, \mathrm{CH}_{3} \mathrm{CO}\right) ;{ }^{13} \mathrm{C} \mathrm{NMR}(100 \mathrm{MHz}$, $\left.\mathrm{CDCl}_{3}\right) \delta 173.7,167.0,144.2,137.7,137.1,132.4,131.1,129.8$, $129.1,128.4,128.2,128.0,127.9,127.6,125.8,123.7,122.2$, $101.4(\mathrm{C}-3), 89.6(\mathrm{C}-11 \mathrm{~b}), 78.4(\mathrm{C}-4 \mathrm{a}), 74.0\left(\mathrm{OCH}_{2} \mathrm{Ph}\right), 73.1(\mathrm{C}-$ 5), $71.5(\mathrm{C}-1), 70.4(\mathrm{C}-11 \mathrm{c}), 63.0\left(\mathrm{C}-6^{\prime}\right), 49.6(\mathrm{C}-6), 21.0\left(\mathrm{CH}_{3-}\right.$ $\mathrm{CO}) ; \mathrm{MS}(\mathrm{ES}+) \mathrm{m} / z=554.3\left[\mathrm{M}+\mathrm{Na}^{+}\right]$.

Compound 15. To a solution of $13(20 \mathrm{mg}, 0.04 \mathrm{mmol})$ in anhydrous toluene $(0.5 \mathrm{~mL})$ was added $\mathrm{PPh}_{3}(10.4 \mathrm{mg}, 0.04$ mmol). After the mixture was stirred at rt for 15 min, DIAD $(11 \mu \mathrm{L}, 0.05 \mathrm{mmol}$ ) was added dropwise, and the mixture was stirred for $5 \mathrm{~h}$. The mixture was diluted with $\mathrm{Et}_{2} \mathrm{O}(10 \mathrm{~mL})$ and washed with a saturated aqueous solution of $\mathrm{NaHCO}_{3}(2$ $\times 3 \mathrm{~mL})$, and brine $(2 \times 3 \mathrm{~mL})$, dried over anhydrous $\mathrm{Na}_{2} \mathrm{SO}_{4}$, 
and concentrated at reduced pressure. The crude was purified by flash chromatography (hexanes/EtOAc 7:1) to give $\mathbf{1 5}$ (18 $\mathrm{mg}, 93 \%)$ as a yellow solid. Mp $109-111^{\circ} \mathrm{C} ;[\alpha]_{\mathrm{D}}{ }^{20}+1.82(c$ $\left.1.1, \mathrm{CHCl}_{3}\right) ;{ }^{1} \mathrm{H} \mathrm{NMR}\left(400 \mathrm{MHz}, \mathrm{CDCl}_{3}\right) \delta 7.80(\mathrm{~d}, 1 \mathrm{H}, J=6.8$ $\mathrm{Hz}), 7.60-7.50(\mathrm{~m}, 4 \mathrm{H}), 7.41-7.23(\mathrm{~m}, 9 \mathrm{H}), 5.81(\mathrm{~s}, 1 \mathrm{H}, \mathrm{H}-3)$, $4.79\left(\mathrm{~d}, 1 \mathrm{H}, J=12 \mathrm{~Hz}, \mathrm{OCH}_{2} \mathrm{Ph}\right), 4.76(\mathrm{~m}, 1 \mathrm{H}, \mathrm{H}-6), 4.74(\mathrm{~d}$, $\left.1 \mathrm{H}, J=12 \mathrm{~Hz}, \mathrm{OCH}_{2} \mathrm{Ph}\right), 4.58(\mathrm{~d}, 1 \mathrm{H}, J=10.4 \mathrm{~Hz}, \mathrm{H}-1 \mathrm{~b})$, $4.42\left(\mathrm{~d}, 1 \mathrm{H}, J=10.0 \mathrm{~Hz}, \mathrm{H}-6^{\prime} \mathrm{b}\right), 4.40(\mathrm{~m}, 1 \mathrm{H}, \mathrm{H}-4 \mathrm{a}), 4.37$ (d, $1 \mathrm{H}, J=10.8 \mathrm{~Hz}, \mathrm{H}-1 \mathrm{a}), 4.09$ (ddd, $1 \mathrm{H}, J=1.2,4.0,9.2 \mathrm{~Hz}$, H-5), 3.99 (ddd, $1 \mathrm{H}, J=1.2,4.4,8.4 \mathrm{~Hz}, \mathrm{H}-6$ 'a), 3.14 (s, $1 \mathrm{H}$, $\mathrm{OH}-11 \mathrm{c}) ;{ }^{13} \mathrm{C} \mathrm{NMR}\left(100 \mathrm{MHz}, \mathrm{CDCl}_{3}\right) \delta 168.5,140.4,137.7$, $136.9,133.8,132.8,130.7,129.2,128.5,128.3,127.9,127.6$, 125.8, 125.0, 123.0, 102.5 (C-3), 97.0 (C-11b), 82.0 (C-4a), 75.2 (C-5), $72.9\left(\mathrm{OCH}_{2} \mathrm{Ph}\right), 71.7\left(\mathrm{C}-6^{\prime}\right), 71.6(\mathrm{C}-11 \mathrm{c}), 71.6(\mathrm{C}-1), 52.7$ (C-6); MS (ES+) $m / z=472.3\left[\mathrm{M}+\mathrm{H}^{+}\right], 494.1\left[\mathrm{M}+\mathrm{Na}^{+}\right]$.

Theoretical Calculations. Molecular mechanics calculations were carried out using the MM2 force field (as implemented in the Chem3D Ultra 9.0 program). All force-field calculations were done in vacuo (dielectric constant $=1$ ). Global minimum energy conformations were obtained by manual construction and subsequent geometry optimization of different combinations of chair, skew, and boat conformations of the two heterocyclic six-membered ring systems of compounds 11 and 12, replacing the benzyl ether groups for methyl ethers to simplify the number of possible conformers of these side chains.

Ab initio calculations were carried out using the Gaussian $98^{23}$ program package at the density functional (B3LYP) level of theory using the 6-311G(d,p) standard basis set. After geometry optimization, analytical frequency calculations were carried out at the same level of theory to determine the nature of the stationary points found and to obtain zero point corrections to energies using standard procedures (no scaling factor was employed in the frequency calculations). The electron affinity is the energy of the neutral molecule minus that of the radical anion $\left(E^{\circ}-E^{-}\right)$. The calculation of the adiabatic electron affinity (AEA) is based on the optimized geometry of the neutral species and the optimized geometry of the radical anion species. The calculation of the vertical electron affinity (VEA) employs the optimized neutral geometry for both neutral and radical anion species.

Acknowledgment. Financial support by the Ministry of Science and Technology of Spain (project BQU2000-1501-C02-01) is gratefully acknowledged.

Supporting Information Available: General experimental procedures, $1 \mathrm{D}\left({ }^{1} \mathrm{H}\right.$ and $\left.{ }^{13} \mathrm{C}\right)$ and $2 \mathrm{D}$ NMR (DQ-COSY, NOESY, HSQC, and HMBC) spectra for compounds 11-15, and energies and Cartesian coordinates for compounds in Table 2. This material is available free of charge via the Internet at http://pubs.acs.org.

JO050185Y 